УДК 550.46

\title{
ИЗМЕНЕНИЯ ХИМИЧЕСКОГО СОСТАВА КИСЛОТНЫХ ВЫТЯЖЕК ПО ГЛУБИНЕ ТОРФЯНОЙ ЗАЛЕЖИ ВНУТРИБОЛОТНЫХ ЭКОСИСТЕМ ВАСЮГАНСКОГО БОЛОТА (ЗАПАДНАЯ СИБИРЬ)
}

\author{
Савичев Олег Геннадьевич', \\ OSavichev@mail.ru
}

\author{
Мазуров Алексей Карпович', \\ AKM@tpu.ru
}
Рудмин Максим Андреевич', RudminMA@tpu.ru

\section{Хващевская Альбина Анатольевна', Garibova@yandex.ru}

\author{
Даулетова Айгерим Бауыржановна', \\ Ikerimdb@gmail.com \\ 1 Национальный исследовательский Томский политехнический университет, \\ Россия, 634050, г. Томск, пр. Ленина, 30.
}

\begin{abstract}
Актуальность работы. Анализ изменений химического и минерального состава органогенных и минеральных грунтов является важным этапом поисков полезных ископаемых, разработки соответствующей методологии, а также методологии экологического мониторинга.

Цель работы: выявление закономерностей изменения химического состава кислотных вытяжек по глубине торфяной залежи на примере восточного участка Васюганского болота.

Методы исследования: ландшафтно-геохимический и статистические методы, методы определения химического и минерального состава, имитационное математическое моделирование.

Результаты и выводы. По данным опробования торфов и минерального грунта в марте 2017 и 2018 гг. в восточной части Васюганского болота (Западная Сибирь, Российская Федерация) выполнен анализ: химического состава кислотных вытяжек из торфов, органо-минеральных отложений и минерального грунта с использованием метода масс-спектрометрии с индуктивно связанной плазмой; состава минеральных включений в торфа и минерального состава подстилающего грунта методом сканирующей электронной микроскопии и рентгенодифракционного анализа. По результатам исследования определены концентрации 73 химических элементов, среди которых выделены три группы: 1) с относительно устойчивым увеличением от поверхности к минеральным грунтам и/или ярко выраженным максимумом в минеральных грунтах; 2) с хорошо выраженными максимумами в верхней и нижней частях разреза; 3) с иными типами распределения. Основными факторами пространственных изменений химического состава грунтов являются преимущественно природные биогеохимические условия, интенсивность водообмена, соотношение атмосферного и грунтового водного и минерального питания, определяющие общую доступность воды и питательных веществ для болотной растительности, отвод токсичных для этой растительности веществ.
\end{abstract}

\section{Ключевые слова:}

Васюганское болото, торф, минеральный грунт, химический состав, минеральный состав, изменение по глубине.

\section{Введение}

Изучение процессов и условий формирования геохимических аномалий в компонентах окружающей среды является важным этапом решения целого ряда разнообразных научных и инженерных задач - от поисков полезных ископаемых до размещения и утилизации бытовых и промышленных отходов. В том числе значительный интерес представляет исследование аккумуляции и выноса химических элементов в торфяных болотах с точки зрения формирования слоев с повышенными концентрациями как непосредственно в них, так и в угольных пластах, сформировавшихся ранее в подобных условиях. С учетом этого в течение нескольких десятилетий в Томском политехническом университете (ТПУ) проводятся комплексные исследования Васюганского болота - одного из крупнейших в мире [1-7]. Его площадь превышает
50 тыс. км² , причем оно продолжает увеличиваться со скоростью вертикального прироста торфа около $1 \mathrm{mм} /$ год [8-10].

В результате ранее проведенных исследований было выполнено обобщение и анализ данных о химическом составе болотных вод в таёжной зоне Западной Сибири, анализ его временных изменений в восточной части Васюганского болота, разработана модель распространения неорганических веществ в загрязнённых водах олиготрофного болота на примере участка Васюганского болота и проведены геомиграционные расчёты, в результате которых показано следующее.

1. Наблюдается общее уменьшение содержаний растворённых солей с юга - юго-запада на север - северо-восток по мере увеличения модулей водного стока и доли верховых болот в заболоченности водосборов, на фоне которого отмечается увеличение 
концентраций большинства изученных веществ: 1.1) от водоразделов к долинам; 1.2 ) на участках с преобладающей лесо-топяной торфяной залежью по сравнению с лесной и топяной [11].

2. В течение 2003-2017 гг. статистически значимые однонаправленные изменения химического состава болотных вод в деятельном горизонте торфяной залежи отсутствуют, а наблюдаемые колебания гидрохимических показателей обусловлены изменчивостью атмосферного увлажнения, которое в годовом разрезе периода 1965-2016 гг. остаётся статистически постоянным, причем: 2.1) гидрохимический режим мезотрофной окраины олиготрофного болота отличается наибольшей изменчивостью минерализации болотных вод и зависимостью от величины атмосферного увлажнения, а гидрохимический режим «ряма» (сосново-кустарничковосфагнового болота) - наименьшим влиянием атмосферного увлажнения; 2.2) общими чертами гидрохимического режима изученных трёх экосистем восточной части Васюганского болота мезотрофной окраины, "ряма», грядово-мочажинного комплекса - является определённое уменьшение минерализации в период весеннего половодья и увеличение соединений N, P, Si и микроэлементов в зимнюю межень [6].

3. Наиболее значительные изменения минерализации болотных вод в результате поступления производственных сточных вод приурочены к верхнему слою толщиной около $0,5-1,0$ м на расстоянии до 200 м от выпуска; создание в деятельном горизонте изоляционного слоя из суглинка помогает снизить воздействие на болотные воды, но не обеспечивает сохранение их фонового состояния в инертном горизонте $[12,13]$.

4. Формирование выпуклого рельефа олиготрофных болотных экосистем возможно в результате приспособления системы «сосна - кустарники - сфагновые мхи» к гидрологическим и гидрогеохимическим условиям и взаимного влияния биотических и абиотических компонентов, когда сосна формирует «фундамент» экосистемы, кустарники - «армирующий слой», а сфагновые мхи выступают в двойственной роли «наполнителя» экосистемы и «стимулятора» вертикального прироста поверхности; при этом олиготрофная болотная экосистема остается неравновесной и непрерывно изменяется в зависимости от гидрогеохимических условий, которые регулируют количество доступных биогенных элементов, кислородный режим торфяной залежи, выведение и трансформацию токсичных продуктов биогеохимических и биохимических процессов [14].

5. В торфяных болотах происходит достаточно резкое уменьшение фильтрационных свойств торфов на границе деятельного и инертного горизонтов и, возможно, у дна торфяной залежи на границе торф - органоминеральные отложения, что способствует снижению интенсивно- сти массообмена между болотной экосистемой и окружающей средой; соответственно увеличивается время взаимодействия воды с торфом и минеральными примесями и затрудняется доступ кислорода. В свою очередь, это способствует формированию окислительного и восстановительного геохимических барьеров и накоплению ряда металлов примерно на глубинах 0,3-0,7 м, в ряде случаев - ниже 0,7 м. Еще одной ключевой особенностью процессов аккумуляции веществ в болотных экосистемах является чрезвычайно важная роль органического вещества, способствующего формированию геохимических аномалий даже при отсутствии расположенных вблизи крупных эндогенных и экзогенных источников вещества $[14,15]$.

Последний вывод был обоснован в основном по данным изучения болотных вод, кислотных и водных вытяжек из торфов в верхней части торфяной залежи, что и обусловило цель рассматриваемой работы - выявление закономерностей изменения химического состава кислотных вытяжек по всей глубине торфяной залежи с подтверждением выводов по геохимии торфов данными о составе минеральных включений в торфах и минеральных грунтов основания торфяного болота (на примере восточного участка Васюганского болота). Целесообразность использования минералогических данных обусловлена тем, что, с одной стороны, повышенные концентрации металлов на фоне разнонаправленных биогеохимических процессов в разрезе торфяного болота способствуют накоплению и/или формированию минеральных форм [16-19]. С другой стороны, в настоящее время остается открытым целый ряд вопросов относительно природы (привнесенные или новообразованные) и источника (антропогенный или литогенный) минералов в торфяной залежи $[7,16,17,20-27]$.

\section{Объекты и методика исследования}

Объектом исследования является восточный участок Васюганского болота на водоразделе рек Бакчар и Икса (93 км по трассе Томск-Бакчар), расположенный в пределах верхней части водосбора реки Ключ (элемент речной сети «Ключ - Бакчар - Чая - Обь - Карское море»). Участок представляет собой сопряжение мезотрофной окраины в виде мезотрофного сосново-кустарничкового болота с участием сфагновых мхов и осоки, олиготрофного сосново-кустарничково-сфагнового болота (олиготрофный «рям», далее - рям) и грядовомочажинного комплекса (ГМК). Наиболее интенсивное формирование болотной экосистемы происходило примерно в последние $3-5$ тыс. лет $[9,28,29]$. По данным [30], максимальная глубина торфа составляет $5,3 \mathrm{~m}$, средняя глубина 1,95 м; торфа - верховые, переходные, низинные, смешанные; средние значения степени разложения торфа $22 \%$, зольности $6 \%$, влажности $90,1 \%$. Более подробное описание участка и прилегающей территории приведено в [6, 29, 31, 32]. 
Исследование включало:

1) отбор в конце зимней межени 2017 и 2018 гг. (при наличии устойчивого снежного покрова) проб торфа, органо-минеральных отложений (ОМО - отложений, в которых органическое вещество составляет от 15 до $50 \%$ сухой массы [33]) и минерального грунта из интервалов 0,25 м по глубине торфяной залежи с уменьшением интервалов до $0,10-0,15$ м при опробовании минерального грунта и ОМО;

2) определение химического состава проб кислотных вытяжек из торфа, ОМО и минерального грунта, а также $\mathrm{pH}$ и удельной электропроводности (EC) водных вытяжек в аккредитованной гидрогеохимической лаборатории ТПУ; пробы торфа предварительно высушивались до воздушно-сухого состояния и растирались в фарфоровой ступке; для анализа водных вытяжек навеска пробы (50-100 г) помещалась в круглодонную колбу с добавлением деионизованной воды (соотношение торфа и воды 1:10), перемешивалась в течение 3 мин, затем проводилось центрифугирование в течение 5 мин; для анализа кислотных вытяжек навеска пробы $(0,2-0,5$ г) помещалась в полиэтиленовую пробирку с добавлением 3 мл азотной кислоты, очищенной с помощью системы Distillasid BSB-939-IR (Berghof, Германия), а затем в микроволновую печь и прогревалась на минимальной мощности (100-300 W) в течение 10 мин. без закипания раствора, затем объем полученного раствора доводился деионизованной водой до 50 мл; методы определения в водной вытяжке: $\mathrm{pH}$ - потенциометрический; удельная электропроводность ЕС кондуктометрический; в кислотной вытяжке 73 химических элементов, включая $\mathrm{Ca}, \mathrm{Mg}, \mathrm{Na}, \mathrm{K}$, $\mathrm{S}, \mathrm{Si}, \mathrm{Al}, \mathrm{Fe}, \mathrm{P}, \mathrm{La}, \mathrm{Ce}, \mathrm{U}$ и другие - масс-спектрометрический с индуктивно-связанной плазмой (масс-спектрометр NexION 300D);

3) расчет коэффициентов влагопроводности $k_{w}$ торфов, ОМО и минерального грунта для оценки влияния интенсивности водообмена на минералого-геохимические условия:

$3.1)$ для торфов согласно [12, 34, 35]:

$$
\begin{gathered}
k_{w}=k_{f}\left(\frac{w-w_{0}}{w_{1}-w_{0}}\right)^{k_{1}}, \\
k_{f}=\frac{k_{2} k_{a}}{\left(Z+k_{3}\right)^{k_{4}}},
\end{gathered}
$$

где $k_{w}$ - коэффициент влагопереноса; $k_{f}$ - коэффициент фильтрации; $Z$ - глубина точки, в которой определяется значение $k_{f}$ (от средней поверхности болота); $k_{a}$ - коэффициент, учитывающий анизотропные свойства торфов; $w$ - объемная влажность торфа на глубине $Z ; w_{0}$ - содержание связанной влаги; $w_{1}$ - влажность при полном насыщении; $k_{1}$, $k_{2}, k_{3}, k_{4}$ - эмпирические коэффициенты; значение коэффициента $k_{1}(3,5)$ принято по данным С.Ф. Аверьянова (приводится по [35]), значения $k_{2}$ $(82,659), k_{3}(1), k_{4}(3,244)$ определены по материалам [36], $k_{a}(0,626)$ - по данным о фильтрационных свойствах торфов Томской области [37, 38]; объемная влажность $w$ (в долях единицы) определена по данным выполненных исследований, значения $w_{0}(0,53)$ и $w_{1}(0,96)$ приняты по данным $[39,40]$ с учетом данных об изменениях $w$ в торфах рассматриваемого участка;

3.2) для ОМО и минерального грунта по Р. Клэппу и Г. Хорнбергу (приводится по [41]):

$$
\begin{gathered}
k_{w}=k_{f, 0}\left(\frac{w}{w_{s}}\right)^{2 B+3}, \\
w_{s}=\left(494,305-1,080 C_{\text {sand }}\right) / 1000, \\
B=0,137 C_{\text {clay }}+3,501,
\end{gathered}
$$

где $k_{f, 0}$ - коэффициент фильтрации в минеральном грунте; $w_{s}-$ пористость; $C_{\text {sand }}$ и $C_{\text {clay }}-$ содержание в пробе песка и глины соответственно; значения $C_{\text {sand }}$ и $C_{\text {clay }}$ оценены по данным рассматриваемого исследования, а значения $k_{f, 0}$ приняты по данным, приведенным в [41], с учетом $C_{\text {sand }}$ и $C_{\text {clay }}$;

4) изучение минеральных включений в торфе и минерального состава подстилающего грунта в ТПУ методом сканирующей электронной микроскопии (CЭM) с использованием микроскопа TESCAN VEGA 3 SBU, оснащенного приставкой для рентгенофлуоресцентного энергодисперсионного анализа (ЭДС) OXFORD X-Max 50, и рентгенодифракционного анализа (РДА) на дифрактометре Rigaku Ultima IV; для определения минеральных включений использовался как сухой остаток торфа, так и его зола, полученная при определение зольности (определение зольности торфа по разнице масс сухой пробы торфа, высушенной при $105^{\circ} \mathrm{C}$, и минеральной части торфа, полученной после прокаливания пробы при температуре $450{ }^{\circ} \mathrm{C}$ в течении 12 ч);

5) обобщение и статистический анализ данных (с помощью пакета MS Excel при уровне значимости $5 \%$ ); корреляционная связь принималась значимой при условии (6), а регрессионная зависимость - при условии, если коэффициенты регрессии по модулю двукратно превышают погрешность их определения, а квадрат корреляционного отношения [42] $R^{2}>0,36$.

$$
|r|>2 \frac{1-r^{2}}{\sqrt{N-1}}
$$

где $r$ - коэффициент корреляции; $N$ - объем выборки. Проверка на однородность по среднему проводилась с использованием критерия Стьюдента $K_{S}$ (7), по дисперсии - с помощью критерия Фишера $K_{F}(8)$ при уровне значимости $5 \%$ :

$$
\begin{gathered}
K_{S}=\frac{\left|A_{x}-A_{y}\right|}{\sqrt{N_{x} D_{x}+N_{y} D_{y}}} \sqrt{\frac{N_{x} N_{y}\left(N_{x}+N_{y}-2\right)}{N_{x}+N_{y}}}, \\
K_{F}=\frac{\max \left(D_{x} ; D_{y}\right)}{\min \left(D_{x} ; D_{y}\right)},
\end{gathered}
$$

где $N_{x}, N_{y}, A_{x}, A_{y}, D_{x}, D_{y}$ - объёмы, средние арифметические и дисперсии сравниваемых выборок $x$ и 
y. Гипотеза об однородности сравниваемых выборок не отвергается, если фактические значения $K_{S}$ и $K_{F}$ меньше критических [43].

\section{Результаты исследования и их обсуждение}

Опробование проводилось по профилю, расположенному примерно перпендикулярно суходолу, покрытому заболоченным смешанным лесом [6]. Самые дальние (от суходола) точки расположены в пределах мочажины (широта $56,939^{\circ}$; долгота $\left.82,698^{\circ}\right)$ и гряды $\left(56,937^{\circ} ; 82,698^{\circ}\right)$ грядово-мочажинного комплекса (от 900 до 1900 м от границы болота и леса). Средняя глубина торфяной залежи исследованного участка ГМК - около 3 м. Непосредственно в точках отбора проб 30.03.2018 г. органо-минеральные отложения в 2018 г. встречены в пределах гряды ГМК на глубине $3,60-3,80$ м, в мочажине - не выявлены. Минеральный грунт, представленный заторфованным суглинком, отмечен в гряде на глубине 3,8 м, в мочажине 3,7 м. Среднее значения $\mathrm{pH}$ водной вытяжки из торфов по глубине торфяной залежи в мочажине составляет 4,42 , в гряде $-4,85$; средние значения удельной электропроводности ЕС в мочажине и гряде - 63,1 и 98,8 мкС/см, соответственно.

Рям на исследуемом участке Васюганского болота расположен в 200-900 м от границы болота (средняя глубина торфяной залежи на участке ряма - 2,8 м). Отбор проб проводился: 23.03.2017 г. в точке с координатами $\left(56,961^{\circ} ; 82,515^{\circ}\right)$ и глубиной торфяной залежи 2,50 м (OMO - на глубине 2,50-2,75 м); 30.03.2018 г. - в точке с координатами $\left(56,928^{\circ} ; 82,700^{\circ}\right)$ и глубиной торфяной залежи 3,75 м (OMO 3,75-4,25 м). Минеральный грунт основания торфяной залежи представлен тяжелым суглинком. Средние значения $\mathrm{pH}$ водных вытяжек из торфа в 2017 г. составили 4,94, в 2018 г. - 5,01; средние значения ЕС - 66,2 и 57,1 мкC/см, соответственно. Мезотрофная окраина представляет собой полосу вдоль заболоченного леса шириной до 200 м и средней глубиной торфяной залежи около 1 м. Опробование проводилось 30.03.2018 г. в точке с глубиной торфяной залежи 1,6 м. ОМО встречены на глубинах 1,60-1,75 м. Минеральный грунт представлен тяжелым и средним суглинками. Среднее значение $\mathrm{pH}$ водных вытяжек из торфа - 5,46, удельной электропроводности - 40,7 мкС/см. Почвенная проба $(0,00-0,10$ м от поверхности) взята в заболоченном лесу в точке с координатами $56,919^{\circ}$ и $82,708^{\circ}$. Значение $\mathrm{pH}$ водной вытяжки из почвы составило 7,2, удельная электропроводность $184,4 \mathrm{м \kappa C/cм} \mathrm{(табл.} 1$ ).

Минеральный состав органо-минеральных отложений и минеральных грунтов основания торфяного болота представлен в основном кварцем, полевыми шпатами и глинистыми минералами. В составе последних отмечено крайне неравномерное распределение смешаннослойных минералов (CCM) и минералов группы смектита, максимумы которых обнаружены в верхнем слое минерального грунта мезотрофной окраины болота. В неболь- шом количестве присутствуют амфиболы, магнетит и карбонаты, причем кальцит не встречен в грунтах мезотрофной окраины болота, а в пределах ГМК его содержание в органо-минеральных отложениях превышает 10 \% . Кроме того, в пределах ряма в 2017 г. в составе минеральных включений в торфа практически по всей глубине торфяной залежи и органо-минеральных отложениях отмечены гидроксиды железа и фосфаты редкоземельных элементов (РЗЭ), в торфе на глубинах $0,00-0,50,1,00-1,50$ м и в минеральном грунте барит, в инертном горизонте торфяной залежи и минеральном грунте - сульфиды $\mathrm{Fe}, \mathrm{Zn}, \mathrm{Pb}$ (табл. 2).

Анализ значений коэффициентов влагопроводности, рассчитанных по формулам (1)-(5), показал, что для болотных экосистем характерно достаточно резкое ухудшение водообмена примерно на глубинах $Z$, соответствующих $0,3-0,4$ и $0,7-0,8$ от глубины обнаружения минерального грунта $Z_{\text {soil }}$ (рис. 1). Диапазон 0,3-0,4 $Z / Z_{\text {soil }}$ может быть сопоставлен с границей деятельного и инертного горизонтов торфяной залежи $[35,36]$ и сменой окислительной обстановки на восстановительную, а диапазон $0,7-0,8 Z / Z_{\text {soil }}$ - с границей наиболее интенсивных взаимодействий органического вещества торфов, болотных вод, растворенных газов и минерального грунта основания торфяного болота $[5,44]$ при существенном возрастании $\mathrm{pH}$ водных вытяжек до 7,5 и более (рис. 2).

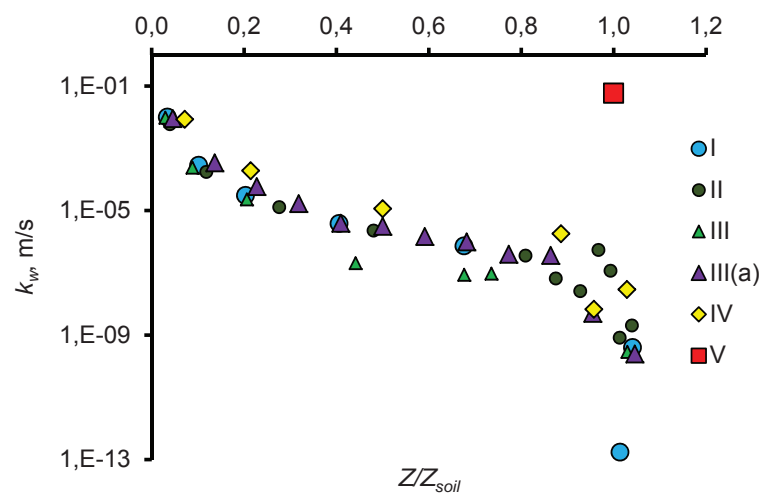

Рис. 1. Изменение значений коэффициентов влагопроводности $k_{w}$ в зависимости от относительной глубины $Z / Z_{\text {soil }}$ в различных экосистемах: Z - средняя глубина интервала опробования; $Z_{\text {soil }}$ - верхняя граница залегания минерального грунта; экосистемы: I - мочажина ГМК в 2018 г.; /I - гряда ГМК в 2018 г.; III и IIIa рям в 2018 и 2017 гг., соответственно; IV - мезотрофное болото между заболоченным лесом и рямом; V заболоченный смешанный лес

Fig. 1. Change of values of soil hydraulic conductivity factors $k_{w}$ depending on relative depth $Z / Z_{\text {soil }}$ in various ecosystems: $Z$ is the average depth of approbation interval; $Z_{\text {soil }}$ is the top border of bottom (mineral) soils; ecosystems: I hollow of the hollow-ridge complex in 2018; II - ridge of the hollow-ridge complex in 2018; III and IIla - ryam the oligotrophic pine-dwarf-shrub-sphagnum bog - in 2018 and 2017 accordingly; IV - the mesotrophic border of an oligotrophic bog; $V$ - the boggy mixed forest 
Известия Томского политехнического университета. Инжиниринг георесурсов. 2018. Т. 329. № 9. 101-116 Савичев О.Г. и др. Изменения химического состава кислотных вытяжек по глубине торфяной залежи внутриболотных ...

Таблица 1. Химический состав кислотных вытяжек из торфов, органо-минеральных отложений, минерального грунта в восточной части Васюганского болота

Table 1. Chemical composition of acid extracts from peats, organic soil and bottom soil in the east part of the Vasyugan mire

\begin{tabular}{|c|c|c|c|c|c|c|c|c|}
\hline \multirow{2}{*}{$\begin{array}{l}\text { Показатель } \\
\text { Index }\end{array}$} & \multicolumn{3}{|c|}{$\begin{array}{l}\text { Средние значения (количество проб) } \\
\text { Average values (amount of tests) }\end{array}$} & \multicolumn{5}{|c|}{$\begin{array}{l}\text { Минеральный грунт и почва } 30.03 .2018 \text { г. в экосистемах } \\
\text { Soils at 30.03.2018 in ecosystems: }\end{array}$} \\
\hline & $\begin{array}{c}\text { торф } \\
\text { peat (32) }\end{array}$ & $\begin{array}{c}\mathrm{OMO} \\
\text { organic soil (4) }\end{array}$ & $\begin{array}{l}\text { грунт } \\
\text { soil (7) }\end{array}$ & $\begin{array}{c}\text { мочажина ГMК } \\
\text { hollow of HRC }\end{array}$ & \begin{tabular}{|c|} 
гряда ГMК \\
ridge of HRC
\end{tabular} & $\begin{array}{l}\text { Pям } \\
\text { ryam }\end{array}$ & $\begin{array}{l}\text { MO } \\
\text { MSOB }\end{array}$ & $\begin{array}{l}\text { лес (почва) } \\
\text { forest (soil) }\end{array}$ \\
\hline$k_{w}, \mathrm{M} / \mathrm{c} / \mathrm{m} / \mathrm{s}$ & $1,41 \cdot 10^{-3}$ & $1,69 \cdot 10^{-7}$ & $4,76 \cdot 10^{-9}$ & $1,77 \cdot 10^{-13}$ & $8,22 \cdot 10^{-10}$ & $2,89 \cdot 10^{-10}$ & $2,95 \cdot 10^{-8}$ & $5,90 \cdot 10^{-2}$ \\
\hline pH, ед. pH/units of pH & 4,91 & 7,74 & 8,24 & 8,35 & 8,33 & 8,26 & 7,84 & 7,20 \\
\hline $\mathrm{EC}, \mathrm{MKC} / \mathrm{CM} / \mu \mathrm{S} / \mathrm{cm}$ & 68,0 & 158,2 & 158,7 & 172,6 & 169,4 & 185,4 & 121,8 & 184,4 \\
\hline \multicolumn{9}{|c|}{$\mathrm{M} \Gamma / \mathrm{K} \Gamma / \mathrm{mg} / \mathrm{kg}$} \\
\hline $\mathrm{Li}$ & 1,313 & 17,312 & 17,547 & 21,767 & 17,025 & 16,612 & 19,221 & 0,830 \\
\hline $\mathrm{Be}$ & 0,105 & 0,875 & 0,836 & 0,927 & 0,771 & 0,835 & 1,133 & 0,099 \\
\hline B & 4,425 & 2,698 & 2,554 & 1,771 & 1,568 & 2,854 & 7,056 & 5,471 \\
\hline $\mathrm{Na}$ & 51 & 108 & 137 & 173 & 124 & 111 & 112 & 133 \\
\hline $\mathrm{Mg}$ & 891 & 5124 & 6453 & 8721 & 5330 & 4861 & 7727 & 1198 \\
\hline $\mathrm{Al}$ & 1633 & 10979 & 10254 & 11363 & 8759 & 8579 & 14649 & 1443 \\
\hline $\mathrm{Si}$ & 436 & 1797 & 2213 & 1563 & 1771 & 3139 & 3141 & 1024 \\
\hline$P$ & 353 & 401 & 400 & 451 & 403 & 426 & 412 & 1302 \\
\hline $\mathrm{s}$ & 1677 & 331 & 364 & 250 & 195 & 401 & 464 & 2063 \\
\hline $\mathrm{Cl}$ & 778 & 174 & 187 & 64 & 241 & 207 & 341 & 671 \\
\hline K & 186 & 1254 & 1551 & 1826 & 1135 & 2260 & 1627 & 1008 \\
\hline $\mathrm{Ca}$ & 9149 & 31972 & 38523 & 45733 & 44066 & 32857 & 12144 & 9172 \\
\hline Sc & 0,408 & 3,392 & 3,553 & 4,249 & 3,438 & 3,442 & 3,838 & 0,286 \\
\hline $\mathrm{Ti}$ & 15,375 & 25,144 & 24,963 & 23,559 & 19,953 & 25,268 & 24,890 & 17,436 \\
\hline V & 4,408 & 27,934 & 29,010 & 28,469 & 31,198 & 27,618 & 30,933 & 5,586 \\
\hline $\mathrm{Cr}$ & 3,631 & 24,706 & 26,035 & 31,565 & 24,407 & 21,873 & 31,003 & 2,900 \\
\hline $\mathrm{Mn}$ & 90,0 & 295,0 & 642,2 & 672,2 & 618,8 & 976,7 & 209,6 & 170,5 \\
\hline $\mathrm{Fe}$ & 2641 & 12736 & 17321 & 20474 & 13789 & 19494 & 17350 & 7136 \\
\hline Co & 1,800 & 11,509 & 13,228 & 14,157 & 12,934 & 13,275 & 13,758 & 6,802 \\
\hline $\mathrm{Ni}$ & 4,584 & 31,325 & 33,125 & 36,308 & 33,295 & 31,060 & 36,901 & 4,756 \\
\hline $\mathrm{Cu}$ & 4,383 & 18,190 & 18,801 & 17,754 & 18,851 & 19,639 & 24,197 & 5,296 \\
\hline $\mathrm{Zn}$ & 43,245 & 37,138 & 40,699 & 44,616 & 37,832 & 44,295 & 51,278 & 32,759 \\
\hline $\mathrm{Ga}$ & 0,576 & 4,355 & 4,334 & 4,994 & 4,040 & 3,889 & 5,263 & 0,528 \\
\hline Ge & 0,028 & 0,137 & 0,141 & 0,168 & 0,156 & 0,108 & 0,143 & 0,069 \\
\hline As & 2,196 & 2,601 & 2,623 & 2,191 & 2,584 & 2,677 & 4,030 & 9,458 \\
\hline $\mathrm{Se}$ & 0,475 & 0,850 & 0,854 & 0,881 & 0,991 & 0,823 & 1,199 & 0,626 \\
\hline $\mathrm{Br}$ & 26,706 & 5,599 & $\begin{array}{l}11,171 \\
\end{array}$ & 10,499 & 26,523 & 2,678 & 4,990 & 60,858 \\
\hline $\mathrm{Rb}$ & 0,845 & 8,106 & 10,089 & 11,523 & 8,337 & 11,054 & 10,749 & 5,838 \\
\hline $\mathrm{Sr}$ & 62,828 & 131,392 & 144,318 & 208,111 & 127,09 & 88,459 & 133,031 & 75,504 \\
\hline$Y$ & 1,091 & 10,853 & 11,519 & 12,328 & 10,841 & 11,666 & 14,364 & 1,143 \\
\hline $\mathrm{Zr}$ & 1,345 & 7,905 & 9,313 & 9,707 & 9,641 & 9,761 & 9,805 & 1,176 \\
\hline $\mathrm{Nb}$ & 0,088 & 0,133 & 0,099 & 0,063 & 0,071 & 0,147 & 0,198 & 0,090 \\
\hline $\mathrm{Mo}$ & 1,035 & 0,104 & 0,117 & 0,041 & 0,078 & 0,259 & 0,242 & 5,339 \\
\hline $\mathrm{Ru}$ & 0,0012 & 0,0056 & 0,0023 & 0,0035 & 0,0037 & 0,0003 & 0,0015 & 0,0003 \\
\hline $\mathrm{Rh}$ & 0,0008 & 0,0012 & 0,0020 & 0,0033 & 0,0019 & 0,0016 & 0,0018 & 0,0012 \\
\hline $\mathrm{Pd}$ & 0,0072 & 0,0488 & 0,0517 & 0,0613 & 0,0523 & 0,0469 & 0,0519 & 0,0012 \\
\hline $\mathrm{Ag}$ & 0,1031 & 0,0478 & 0,0356 & 0,0362 & 0,0262 & 0,0316 & 0,0715 & 0,0420 \\
\hline $\mathrm{Cd}$ & 0,1130 & 0,1179 & 0,1324 & 0,1468 & 0,1140 & 0,1666 & 0,1505 & 0,5172 \\
\hline $\ln$ & 0,0033 & 0,0165 & 0,0164 & 0,0189 & 0,0168 & 0,0164 & 0,0170 & 0,0049 \\
\hline Sn & 0,0764 & 0,0322 & 0,0206 & 0,0166 & 0,0177 & 0,0204 & 0,0136 & 0,1629 \\
\hline $\mathrm{Sb}$ & 0,1342 & 0,0241 & 0,0185 & 0,0165 & 0,0164 & 0,0181 & 0,0178 & 0,3367 \\
\hline $\mathrm{Te}$ & 0,0093 & 0,0060 & 0,0185 & 0,0168 & 0,0056 & 0,0500 & 0,0155 & 0,0368 \\
\hline 1 & 6,588 & 9,448 & 11,627 & 11,143 & 26,036 & 0,770 & 11,495 & 29,257 \\
\hline $\mathrm{CS}$ & 0,094 & 0,653 & 0,766 & 0,881 & 0,750 & 0,647 & 0,706 & 0,316 \\
\hline $\mathrm{Ba}$ & 30,9 & 141,9 & 141,0 & 150,4 & 141,6 & 121,6 & 171,8 & 41,2 \\
\hline La & 1,4058 & 14,6135 & 14,2380 & 13,8117 & 12,868 & 14,637 & 18,9763 & 1,7602 \\
\hline $\mathrm{Ce}$ & 3,130 & 34,456 & 32,277 & 30,724 & 28,843 & 34,150 & 43,104 & 3,163 \\
\hline $\mathrm{Pr}$ & 0,3549 & 3,7768 & 3,7055 & 3,5749 & 3,4099 & 3,9116 & 4,8226 & 0,3671 \\
\hline $\mathrm{Nd}$ & 1,414 & 14,957 & 15,018 & 15,076 & 13,688 & 16,101 & 18,975 & 1,494 \\
\hline Sm & 0,3035 & 3,1212 & 3,1819 & 3,1343 & 2,9195 & 3,3899 & 4,1614 & 0,3205 \\
\hline Eu & 0,0704 & 0,7179 & 0,6993 & 0,6697 & 0,6336 & 0,7480 & 0,8841 & 0,0697 \\
\hline $\mathrm{Gd}$ & 0,3181 & 3,2298 & 3,2365 & 3,2426 & 2,9614 & 3,4514 & 4,1541 & 0,3176 \\
\hline $\mathrm{Tb}$ & 0,0436 & 0,4396 & 0,4369 & 0,4353 & 0,3966 & 0,4735 & 0,5535 & 0,0426 \\
\hline
\end{tabular}


Известия Томского политехнического университета. Инжиниринг георесурсов. 2018. Т. 329. № 9. 101-116 Савичев О.Г. и др. Изменения химического состава кислотных вытяжек по глубине торфяной залежи внутриболотных ...

\section{Окончание табл. 1}

\section{Table 1}

\begin{tabular}{|c|c|c|c|c|c|c|c|c|}
\hline \multirow{2}{*}{$\begin{array}{l}\text { Показатель } \\
\text { Index }\end{array}$} & \multicolumn{3}{|c|}{$\begin{array}{l}\text { Средние значения (количество проб) } \\
\text { Average values (amount of tests) }\end{array}$} & \multicolumn{5}{|c|}{$\begin{array}{l}\text { Минеральный грунт и почва 30.03.2018 г. в экосистемах } \\
\text { Soils at 30.03.2018 in ecosystems: }\end{array}$} \\
\hline & $\begin{array}{c}\text { торф } \\
\text { peat (32) }\end{array}$ & $\begin{array}{c}\mathrm{OMO} \\
\text { organic soil (4) }\end{array}$ & $\begin{array}{l}\text { грунт } \\
\text { soil (7) }\end{array}$ & $\begin{array}{c}\text { мочажина ГMК } \\
\text { hollow of HRC }\end{array}$ & \begin{tabular}{|c|} 
гряда ГMK \\
ridge of HRC
\end{tabular} & $\begin{array}{l}\text { Pям } \\
\text { ryam }\end{array}$ & $\begin{array}{l}\mathrm{MO} \\
\mathrm{MSOB}\end{array}$ & $\begin{array}{l}\text { лес (почва) } \\
\text { forest (soil) }\end{array}$ \\
\hline Dy & 0,2293 & 2,3650 & 2,3994 & 2,3942 & \begin{tabular}{|l|}
2,2443 \\
\end{tabular} & 2,5870 & 2,9931 & 0,2368 \\
\hline $\mathrm{Ho}$ & 0,0413 & 0,4231 & 0,4271 & 0,4200 & 0,3921 & 0,4646 & 0,5529 & 0,0433 \\
\hline $\mathrm{Er}$ & 0,1102 & 1,1373 & 1,1217 & 1,1190 & 1,0218 & 1,1862 & 1,4298 & 0,1073 \\
\hline $\mathrm{Tm}$ & 0,0153 & 0,1527 & 0,1481 & 0,1471 & 0,1354 & 0,1600 & 0,1857 & 0,0141 \\
\hline $\mathrm{Yb}$ & 0,0938 & 0,9630 & 0,9477 & 0,9805 & 0,8555 & 1,0526 & 1,1617 & 0,0893 \\
\hline Lu & 0,0134 & 0,1348 & 0,1311 & 0,1295 & 0,1237 & 0,1421 & 0,1574 & 0,0125 \\
\hline $\mathrm{Hf}$ & 0,0503 & 0,2699 & 0,3122 & 0,3582 & 0,3482 & 0,3093 & 0,2734 & 0,0483 \\
\hline $\mathrm{Ta}$ & 0,0185 & 0,0046 & 0,0048 & 0,0007 & 0,0023 & 0,0009 & 0,0029 & 0,0114 \\
\hline W & 0,0326 & 0,0197 & 0,0127 & 0,0007 & 0,0152 & 0,0082 & 0,0133 & 0,0953 \\
\hline $\mathrm{Re}$ & 0,0007 & 0,0051 & 0,0058 & 0,0001 & 0,0001 & 0,0001 & 0,0001 & 0,0014 \\
\hline Os & 0,0074 & 0,0100 & 0,0172 & 0,0200 & 0,0200 & 0,0200 & 0,0200 & 0,0050 \\
\hline Ir & 0,0011 & 0,0007 & 0,0033 & 0,0000 & 0,0006 & 0,0005 & 0,0010 & 0,0000 \\
\hline $\mathrm{Pt}$ & 0,0006 & 0,0017 & 0,0016 & 0,0019 & 0,0016 & 0,0023 & 0,0020 & 0,0006 \\
\hline $\mathrm{Au}$ & 0,0103 & 0,0041 & 0,0017 & 0,0007 & 0,0019 & 0,0018 & 0,0014 & 0,0146 \\
\hline $\mathrm{Hg}$ & 0,0939 & 0,0481 & 0,0450 & 0,0056 & 0,0275 & 0,1693 & 0,0391 & 0,4524 \\
\hline $\mathrm{Tl}$ & 0,0165 & 0,0808 & 0,0796 & 0,0885 & 0,0714 & 0,0760 & 0,0964 & 0,0964 \\
\hline $\mathrm{Pb}$ & 3,622 & 12,175 & 12,353 & 12,613 & 11,613 & 13,221 & 13,970 & 11,171 \\
\hline $\mathrm{Bi}$ & 0,0388 & 0,1397 & 0,1563 & 0,1613 & 0,1490 & 0,1717 & 0,1505 & 0,0958 \\
\hline Th & 0,281 & 4,428 & 4,875 & 5,016 & 4,762 & 5,203 & 5,081 & 0,095 \\
\hline$U$ & 0,756 & 0,996 & 0,934 & 1,303 & 0,847 & 0,585 & 1,121 & 0,154 \\
\hline
\end{tabular}

Примечание: ГМК - грядово-мочажинный комплекс; рям - сосново-сфагново-кустарничковое болото; МО - мезотрофная окраина болота; $E C$ - удельная электропроводность; $k_{w}-$ коэффициент влагопроводности $(1,3)$.

Note: HRC is the hollow-ridge complex - mire type which combines low elongated ridges and hollows between them; ryam (Russian) is the oligotrophic pine-dwarf-shrub-sphagnum raised bog; MSOB is the mesotrophic border of an oligotrophic bog; EC-electric conductivity; $k_{w}$ - factors of soil hydraulic conductivity $(1,3)$.

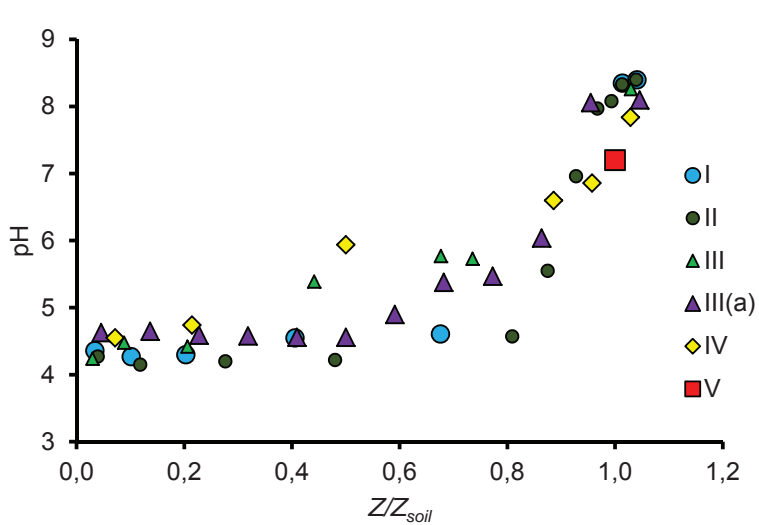

Рис. 2. Изменение значений рН водных вытяжек в зависимости от относительной глубины $Z / Z_{\text {soil }}$ в различных экосистемах: Z - средняя глубина интервала опробования; $Z_{\text {soil }}$ - верхняя граница залегания минерально го грунта; экосистемы: I - мочажина ГМК в 2018 г.; II - гряда ГМК в 2018 г.; III и IIIa - рям в 2018 и 2017 гг., соответственно; IV - мезотрофное болото между заболоченным лесом и рямом; $V$ - заболоченный смешанный лес

Fig. 2. Change of $\mathrm{pH}$-values depending on relative depth $\mathrm{Z} / \mathrm{Z}_{\text {soil }}$ in various ecosystems: $Z$ is the average depth of approbation interval; $Z_{\text {soi }}$ is the top border of bottom (mineral) soils; ecosystems: I - hollow of the hollow-ridge complex in 2018; II - ridge of the hollow-ridge complex in 2018; III and IIIa - ryam in 2018 and 2017 accordingly; IV - the mesotrophic border of an oligotrophic bog; $V$ - the boggy mixed forest
С учетом этого, а также с учетом изменений свойств грунтов, выявленных визуально при отборе проб, данные о химическом составе кислотных вытяжек были разделены по слоям: 1) торф на глубинах $<0,3 Z / Z_{\text {soil }}, 0,3-0,7 Z / Z_{\text {soil }},>0,7 Z / Z_{\text {soil }}$; 2) opгано-минеральные отложения; 3) минеральный грунт. Затем при уровне значимости 5 \% выполнена проверка полученных данных на однородность по дисперсии и среднему для трех выборок - торфов, ОМО и минерального грунта. В результате установлено, что наиболее существенные различия закономерно отмечаются между торфами, с одной стороны, и минеральным грунтом и органоминеральными отложениями, с другой. Гипотеза об однородности выборок не была отклонена только для концентраций $\mathrm{B}, \mathrm{P}, \mathrm{Sr}, \mathrm{Rh}, \mathrm{Cd}, \mathrm{Te}, \mathrm{I}, \mathrm{W}, \mathrm{Os}$, $\mathrm{Pt}, \mathrm{Au}$ в паре «торф-OMO» и концентраций $\mathrm{Nb}$, $\mathrm{Ru}, \mathrm{W}, \mathrm{Hg}$ в паре «OMO - минеральный грунт». Различия между ОМО и минеральным грунтом выявлены для значений $\mathrm{pH}$ и удельной электропроводности водных вытяжек, концентраций $\mathrm{Mn}, \mathrm{Br}$, $\mathrm{Ru}, \mathrm{In}, \mathrm{Sb}, \mathrm{Te}, \mathrm{Ta}, \mathrm{Ir}, \mathrm{Au}$.

По полученным результатам все изученные химические элементы можно условно разделить на группы: 1) с относительно устойчивым увеличением от поверхности к минеральным грунтам и/или ярко выраженным максимумом в минеральных грунтах - Li, Al, Be, Mg, Ca, Sr, Fe, V, Cr, Mn, Ni, J, Ba, Cs, Ce, La, Sm, Eu, Dy, Tb, Yb, Lu, Ho, Gd, Th 
Таблица 2. Состав минеральных включений в торфа, минеральный состав органо-минеральных отложений и минерального грунта в ряме в 2017 г.

Table 2. Composition of mineral inclusions in peat, mineral composition of organic and bottom soils in oligotrophic pine-dwarfshrub-sphagnum bog (ryam) in 2017

\begin{tabular}{|c|c|c|c|c|c|c|}
\hline & Интервал & & & & $P$ & $S$ \\
\hline $\begin{array}{c}\text { Грунт } \\
\text { Soil - Peat }\end{array}$ & $\begin{array}{l}\text { глубин, м } \\
\text { Depth in- } \\
\text { terval, } m\end{array}$ & $\begin{array}{l}\text { Минеральный состав } \\
\text { Mineral composition }\end{array}$ & $\sum_{\substack{\text { ș } \\
\Sigma}}^{\infty} \frac{n}{\varepsilon}$ & 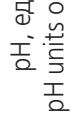 & \multicolumn{2}{|c|}{$\begin{array}{l}\mathrm{M \Gamma} / \mathrm{K \Gamma} \\
\mathrm{mg} / \mathrm{kg}\end{array}$} \\
\hline $\begin{array}{l}\text { Торф, очес } \\
\text { Peat, root layer }\end{array}$ & $0,00-0,25$ & $\begin{array}{l}\text { включения: гидроксид (оксид) железа, монацит, барит, циркон, хромит, } \\
\text { кварц, касситерит } \\
\text { inclusions: iron hydroxide (oxide), monazite, barite, zircon, chromite, quartz, cas- } \\
\text { siterite }\end{array}$ & $9,1 \cdot 10^{-3}$ & 4,63 & 383 & 1135 \\
\hline \multirow{9}{*}{$\begin{array}{l}\text { Topф } \\
\text { Peat }\end{array}$} & $0,25-0,50$ & $\begin{array}{l}\text { включения: гидроксид (оксид) железа, монацит, барит, циркон, ильменит, } \\
\text { рутил, хромит } \\
\text { inclusions: iron hydroxide (oxide), monazite, barite, zircon, ilmenite, rutile, chromite }\end{array}$ & $3,4 \cdot 10^{-4}$ & 4,65 & 356 & 2405 \\
\hline & $0,50-0,75$ & $\begin{array}{l}\text { включения: гидроксид (оксид) железа, циркон, хромит, кварц, каолинит, } \\
\text { кальцит, пирит, галенит, сфалерит } \\
\text { inclusions: iron hydroxide (oxide), zircon, chromite, quartz, kaolinite, calcite, pyri- } \\
\text { te, galena, sphalerite }\end{array}$ & $6,0 \cdot 10^{-5}$ & 4,59 & 237 & 1450 \\
\hline & $0,75-1,00$ & $\begin{array}{l}\text { включения: гидроксид (оксид) железа, монацит, ксенотим, циркон, хромит } \\
\text { inclusions: iron hydroxide (oxide), monazite, xenotime, zircon, chromite }\end{array}$ & $1,7 \cdot 10^{-5}$ & 4,58 & 220 & 1578 \\
\hline & $1,00-1,25$ & $\begin{array}{l}\text { включения: барит, монацит, циркон, ильменит, рутил/inclusions: barite, mo- } \\
\text { nazite, zircon, ilmenite, rutile }\end{array}$ & $3,9 \cdot 10^{-6}$ & 4,56 & 179 & 1596 \\
\hline & $1,25-1,50$ & $\begin{array}{l}\text { включения: монацит, ксенотим, барит, циркон, ильменит, кальцит, кварц, } \\
\text { пирит, галенит/inclusions: monazite, xenotime, barite, zircon, ilmenite, calcite, } \\
\text { quartz, pyrite, galena }\end{array}$ & $3,2 \cdot 10^{-6}$ & 4,56 & 622 & 2137 \\
\hline & $1,50-1,75$ & $\begin{array}{l}\text { включения: гидроксид (оксид) железа, монацит, ксенотим, циркон inclusions: } \\
\text { iron hydroxide (oxide), monazite, xenotime, zircon }\end{array}$ & $1,5 \cdot 10^{-6}$ & 4,90 & 420 & 2206 \\
\hline & $1,75-2,00$ & $\begin{array}{l}\text { включения: монацит, ксенотим, циркон, магнетит, кальцит, кварц, пирит, иллит } \\
\text { inclusions: monazite, xenotime, zircon, magnetite, calcite, quartz, pyrite, illite }\end{array}$ & $9,9 \cdot 10^{-7}$ & 5,38 & 554 & 2716 \\
\hline & $2,00-2,25$ & $\begin{array}{l}\text { включения: кварц, монацит, циркон, кальцит, кварц, пирит, иллит, рутил, } \\
\text { стибнит } \\
\text { inclusions: quartz, monazite, zircon, calcite, quartz, pyrite, illite, rutile, stibnite }\end{array}$ & $4,0 \cdot 10^{-7}$ & 5,47 & 369 & 2519 \\
\hline & $2,25-2,50$ & $\begin{array}{l}\text { кварц (31,4 \%), глауконит (3,3 \%), иллит (44,8 \%), хлорит (4,0 \%), плагио- } \\
\text { клаз (16,4 \%); включения: монацит, ксенотим, циркон, ильменит, золото } \\
\text { quartz (31,4 \%), glauconite }(3,3 \text { \%), illite }(44,8 \%) \text {, chlorite }(4,0 \%) \text {, plagioclase } \\
(16,4 \%) \text {; inclusions: monazite, xenotime, zircon, ilmenite, gold }\end{array}$ & $3,7 \cdot 10^{-7}$ & 6,04 & 491 & 2018 \\
\hline $\begin{array}{l}\text { OMO } \\
\text { Organic soil }\end{array}$ & $2,50-2,75$ & 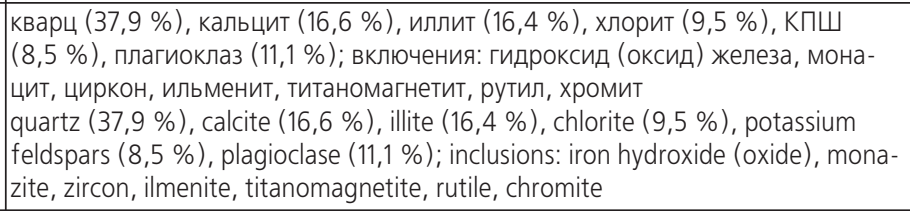 & $5,1 \cdot 10^{-9}$ & 8,06 & 255 & 261 \\
\hline $\begin{array}{c}\text { Минеральный } \\
\text { грунт } \\
\text { Soil }\end{array}$ & $2,75-3,00$ & $\begin{array}{l}\text { кварц (34,1%), кальцит (17,2 \%), иллит (16,6%), хлорит (11,2%), КПШ } \\
(8,6 \text { \%), плагиоклаз (12,3%); включения: гидроксид (оксид) железа, ксено- } \\
\text { тим, пирит, галенит, сфалерит, барит, целестин, циркон, ильменит, титано- } \\
\text { магнетит } \\
\text { quartz (34,1 \%), calcite (17,2 \%), illite (16,6 \%), chlorite (11,2 \%), potassium } \\
\text { feldspars (8,6 \%), plagioclase (12,3%); inclusions: iron hydroxide (iron oxide), } \\
\text { xenotime, pyrite, galena, sphalerite, barite, celestite, zircon, ilmenite, titanomag- } \\
\text { netite }\end{array}$ & $2,5 \cdot 10^{-10}$ & 8,10 & 268 & 225 \\
\hline
\end{tabular}

(рис. 3), а также с небольшим (по сравнению с максимумом в минеральном грунте) повышением концентраций в верхней части разреза $\mathrm{Cu}, \mathrm{Ga}, \mathrm{Ge}, \mathrm{Rb}$, $\mathrm{Zr}, \mathrm{Hf} ; 2$ ) с хорошо выраженными максимумами в верхней и нижней частях разреза - $\mathrm{Na}, \mathrm{K}, \mathrm{Ti}, \mathrm{Pb}$, $\mathrm{Hg}, \mathrm{Rb}, \mathrm{Cd}, \mathrm{Sb}, \mathrm{Sn}, \mathrm{W}, \mathrm{Bi}, \mathrm{Si}$, в том числе с резко выраженной дифференциацией по разрезу $\mathrm{Pb}$ и $\mathrm{Bi}$ (рис. 4); 3) с иными типами распределения (включая максимумы в слоях торфа или в ОМО) - S, P, $\mathrm{U}, \mathrm{Au}, \mathrm{Ag}, \mathrm{Pt}, \mathrm{Zn}, \mathrm{As}, \mathrm{Re}, \mathrm{Os}, \mathrm{B}, \mathrm{Br}, \mathrm{Ta}$ (рис. 5).
Для $\mathrm{pH}$ и удельной электропроводности водных вытяжек, концентраций большинства изученных элементов в кислотных вытяжках наблюдается уменьшение концентраций в направлении «минеральный грунт $\rightarrow \mathrm{OMO} \rightarrow$ торф» (Li, Na, Mg, $\mathrm{Si}, \mathrm{K}$, $\mathrm{Ca}, \mathrm{Sc}, \mathrm{V}, \mathrm{Cr}, \mathrm{Mn}, \mathrm{Fe}, \mathrm{Co}, \mathrm{Ni}, \mathrm{Cu}, \mathrm{Ge}, \mathrm{As}, \mathrm{Se}, \mathrm{Rb}, \mathrm{Sr}$, Y, Zr, Rh, Pd, Cd, I, Cs, Nd, Sm, Gd, Dy, Ho, Hf, Re, $\mathrm{Os}, \mathrm{Pb}, \mathrm{Bi}, \mathrm{Th})$. Обратная зависимость (увеличение концентраций в направлении «минеральный грунт $\rightarrow \mathrm{OMO} \rightarrow$ торф») выявлена для $\mathrm{B}, \mathrm{Ag}, \mathrm{Sn}, \mathrm{Sb}$, 
W, Au, Hg. Также следует отметить, что максимумы в торфах установлены для S, Cl, Zn, Br, Mo, Ta. Максимальные концентрации в ОМО при общем снижении в ряду «ОМО - минеральный грунт торф» зафиксированы для достаточно большого количества химических элементов: $\mathrm{Be}, \mathrm{Al}, \mathrm{P}, \mathrm{Ti}$, $\mathrm{Ga}, \mathrm{Nb}, \mathrm{Ru}, \mathrm{In}, \mathrm{Ba}, \mathrm{La}, \mathrm{Ce}, \mathrm{Pr}, \mathrm{Eu}, \mathrm{Tb}, \mathrm{Er}, \mathrm{Tm}, \mathrm{Yb}$, $\mathrm{Lu}, \mathrm{Pt}, \mathrm{Tl}, \mathrm{U}$.

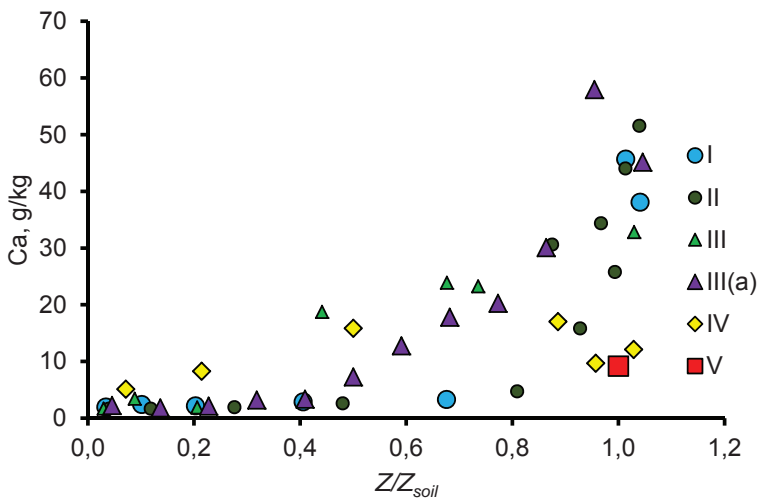

Pис. 3. Изменение концентраций Са в кислотных вытяжках в зависимости от относительной глубины $Z / Z_{\text {soil }}$ в различных экосистемах: Z - средняя глубина интервала опробования; $Z_{\text {soil }}$ - верхняя граница залегания минерального грунта; экосистемы: I - мочажина ГМК в 2018 г.; II - гряда ГМК в 2018 г.; III и IIIa - рям в 2018 и 2017 гг. соответственно; IV - мезотрофное болото между заболоченным лесом и рямом; $\mathrm{V}$ - заболоченный смешанный лес

Fig. 3. Change of Ca concentration depending on relative depth $Z / Z_{\text {soil }}$ in various ecosystems: $Z$ is the average depth of approbation interval; $Z_{\text {soil }}$ is the top border of bottom (mineral) soils; ecosystems: I - hollow of the hollow-ridge complex in 2018; II - ridge of the hollow-ridge complex in 2018; III and IIIa - ryam in 2018 and 2017 accordingly $\mathrm{IV}$ - the mesotrophic border of an oligotrophic bog; $\mathrm{V}$ the boggy mixed forest

Связь концентраций химических элементов в кислотных вытяжках из ОМО и минерального грунта с соответствующим минеральным составом отмечена, прежде всего, между РЗЭ, с одной стороны, и содержанием минералов группы смектита и смешаннослойных минералов в \% от суммы глинистых минералов (рис. 6) - с другой. Соответствующие коэффициенты корреляции составляют от 0,55 до 0,80 , причем с содержанием каолинита статистически значимые связи не выявлены. Монтмориллонит и другие минералы группы смектита обладают более высокой сорбционной способностью, чем минералы группы каолинита, а при одновременном их набухании и насыщении натрием вероятно снижение проницаемости и разрушение структуры [45], что, видимо, и является причиной возможных в болотной среде превращений монтмориллонита в каолинит [46]. Этот процесс, прежде всего, протекает в пределах мезотрофной окраины, где имеется источник вещества (по данным А.И. Сысо [47], монтмориллонит обычно входит в состав илистой фракции почв ра- йона, примыкающего к Васюганскому болоту с юга и характеризующегося более высокими высотными отметками), а на границе болота (вследствие различной водопропускной способности болотной и лесной экосистем) скапливаются водные массы [48]. Это и подтверждается данными о повышенном содержании смектита на этом участке (рис. 6).

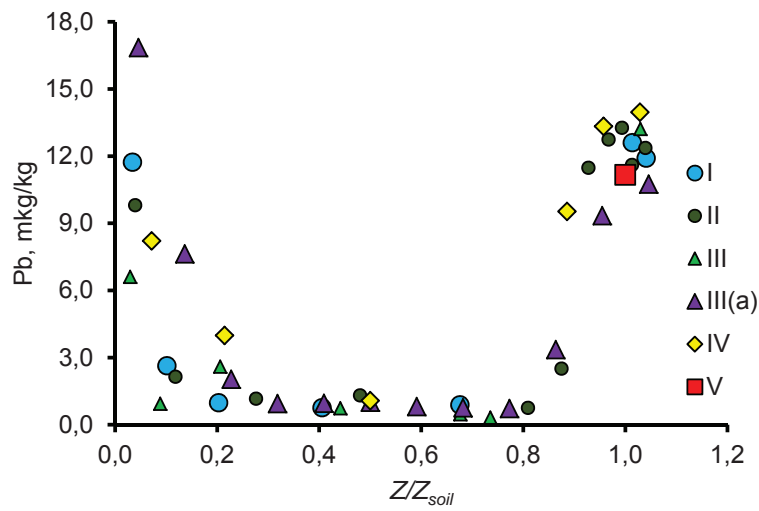

Рис. 4. Изменение концентраций РЬ в кислотных вытяжках в зависимости от относительной глубины $Z / Z_{\text {soil }}$ В различных экосистемах: Z - средняя глубина интервала опробования; $Z_{\text {soil }}$ - верхняя граница залегания минерального грунта; экосистемы: I - мочажина ГМК в 2018 г.; II - гряда ГМК в 2018 г.; III и ІІІа - рям в 2018 и 2017 гг. соответственно; IV - мезотрофное болото между заболоченным лесом и рямом; $\mathrm{V}$ - заболоченный смешанный лес

Fig. 4. Change of $\mathrm{Pb}$ concentration depending on relative depth $Z / Z_{\text {soil }}$ in various ecosystems: $Z$ is the average depth of approbation interval; $Z_{\text {soil }}$ is the top border of bottom (mineral) soils; ecosystems: I - hollow of the hollow-ridge complex in 2018; II - ridge of the hollow-ridge complex in 2018; III and IIIa - ryam in 2018 and 2017 accordingly; IV - the mesotrophic border of an oligotrophic bog; V the boggy mixed forest

При разрушении минералов группы смектита (в составе атмосферного аэрозоля на олиготрофных участках и выноса с суходолов на меотрофной окраине болота) в водную среду, предположительно, поступает определенное количество химических элементов, включая РЗЭ, находившихся ранее в структуре минерала либо сорбированных на его поверхности. В дальнейшем уровень содержания химических элементов в деятельном горизонте (до 0,3-0,5 м от поверхности), в пределах которого преобладает окислительная обстановка, определяется биоаккумуляцией и способностью образовывать с органическими веществами либо устойчивые комплексы, способствующие миграции и накоплению в болотных водах (например, комплексы $\mathrm{Fe}^{3+}$ и фульвокислот ФК), либо малорастворимые соединение (соединения гуминовых кислот ГК с $\mathrm{Ca}, \mathrm{Mg}$ и рядом других металлов за исключением $\mathrm{K}$ и $\mathrm{Na}$ ) [49-51]. Одновременно происходит образование малорастворимых фосфатов и их соосаждение с гидроксидами и оксидами железа по всей глубине торфяной залежи и кальцитом - в ее нижней части, в которой увеличивается и присутствие твердого вещества, и содержание углекисло- 
го газа в результате разложения органического вещества, что подтверждается данными о включениях в торфа фосфатов РЗЭ, а также опубликованными сведениями других авторов о минералообразовании в болотах и почвах [22, 52].

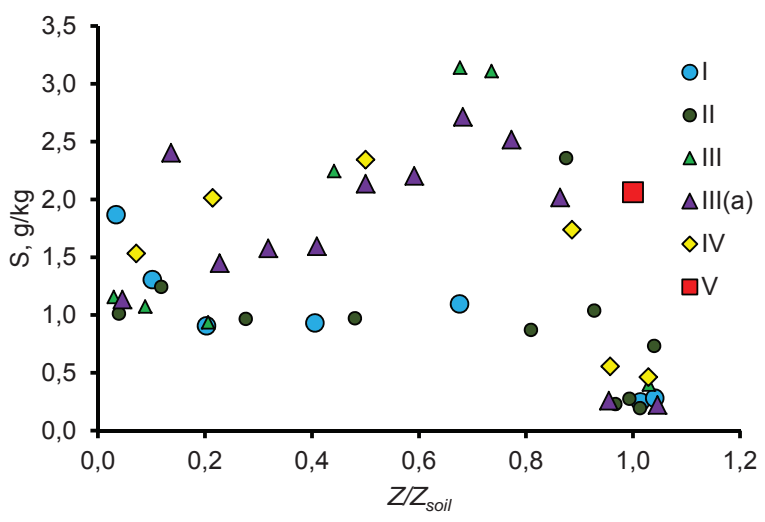

Рис. 5. Изменение концентраций S в кислотных вытяжках в зависимости от относительной глубины $Z / Z_{\text {soil }} B$ различных экосистемах: Z - средняя глубина интервала опробования; $Z_{\text {soil }}$ - верхняя граница залегания минерального грунта; экосистемы: I - мочажина ГМК в 2018 г.; II - гряда ГМК в 2018 г.; III и IIIa - рям в 2018 и 2017 гг. соответственно; IV - мезотрофное болото между заболоченным лесом и рямом; V-заболоченный смешанный лес

Fig. 5. Change of $S$ concentration depending on relative depth $Z / Z_{\text {soil }}$ in various ecosystems: $Z$ is the average depth of approbation interval; $Z_{\text {soil }}$ is the top border of bottom (mineral) soils; ecosystems: I - hollow of the hollow-ridge complex in 2018; II - ridge of the hollow-ridge complex in 2018; III and IIIa - ryam in 2018 and 2017 accordingly; IV - the mesotrophic border of an oligotrophic bog; Vthe boggy mixed forest

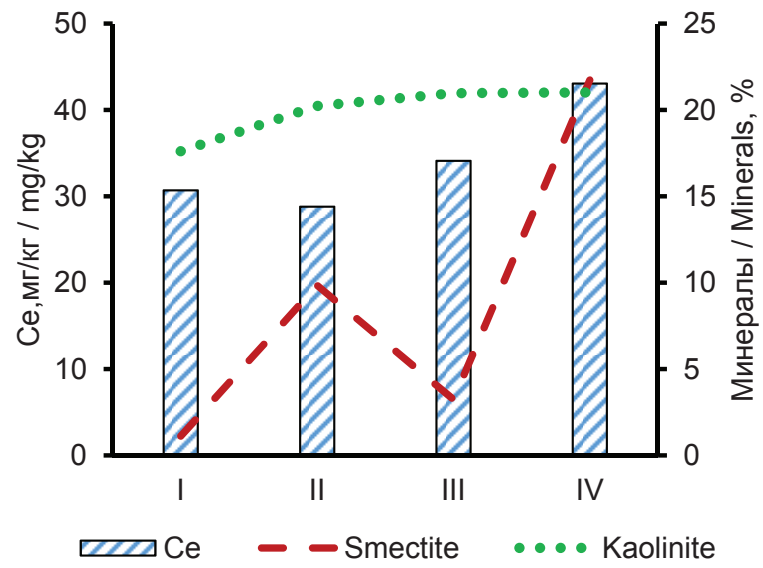

Рис. 6. Изменение концентраций Се в кислотных вытяжках доли смектита и каолинита в верхнем слое минерального грунта в 2018 г. в различных экосистемах: I - мочажина ГМК; II - гряда ГМК; III - рям; IV - мезотрофное болото между заболоченным лесом и ряMOM

Fig. 6. Change of Ce concentration in acid extracts, shares of smectite and kaolinite in the top layer of bottom (mineral) soils in 2018 in various ecosystems: I - hollow of the hollow-ridge complex in 2018; II - ridge of the hollowridge complex in 2018; III - ryam; IV - the mesotrophic border of an oligotrophic bog
В общих чертах такой механизм характерен не только для РЗЭ, но и для многих других элементов. Например, кремний, поступающий в болотную среду первоначально при выщелачивании первичных алюмосиликатов $[5,53]$, находящихся в составе частиц минерального грунта суходола или частиц атмосферного аэрозоля, усваивается болотной растительностью в летний период и аккумулируется в болотных водах в осенне-зимний период. В результате максимальные концентрации $\mathrm{Si}$ в болотных водах мезотрофной окраины обычно наблюдаются в зимний период вследствие накопления продуктов разложения растительного материала, а минимальные - в весенний, когда происходит разбавление болотных вод талыми снеговыми. В пределах ряма нет такого интенсивного поступления снеготалых вод, как на окраине болота. Поэтому разбавление происходит в меньшей степени, а в сезонном изменении концентраций $\mathrm{Si}$ наиболее очевидной тенденцией является определенное их снижение в летний период [6].

В разрезе торфяной залежи, как было указано выше, с глубиной торфяной залежи происходит ухудшение фильтрационных свойств (рис. 1) и доступа кислорода, что способствует формированию в пределах инертного горизонта торфяной залежи восстановительной обстановки за счет автотрофной и гетеротрофной сульфатредукции. Согласно [54], в первом случае происходит окисление водорода с последующим увеличением $\mathrm{pH}$, а во втором - окисление органических веществ и уменьшение $\mathrm{pH}$, которое при определенных условиях может компенсироваться процессами метанообразования, протекающими и на территории Васюганского болота [55]. Наблюдаемое распределение pH водных вытяжек из торфов (рис. 2) свидетельствует, видимо, о наличии таких условий на рассматриваемом участке Васюганского болота либо о преобладании автотрофной сульфатредукции на олиготрофных участках болота. В любом случае увеличение $\mathrm{pH}$ соответствует повышению концентраций $\mathrm{CO}_{3}^{2-}$ и возможности осаждения кальцита, что подтверждается данными о минеральном составе ОМО и минерального грунта в пределах олиготрофных внутриболотных экосистем, а также данными о содержании в торфах фульво- и гуминовых кислот, включая фракцию ГК-2, предположительно связанную с кальцием [31, 32].

Торфяная залежь формируется в результате комплекса дискретных случайных процессов, в результате которых она представляет собой принципиально неоднородную по фильтрационным и геохимическим свойствам среду, причем не всегда понятно, нужно ли рассматривать болото как единую экосистему, либо как комплекс сопряженных экосистем. Например, мезотрофная окраина рассматриваемого участка формируется за счет «наползания» олиготрофного болота на покрытый смешанным лесом суходол вследствие создания и перемещения в сторону леса переувлажненной полосы, а рям, наблюдаемый в настоящее время, сформиро- 
вался, видимо, на месте размещения малых водоемов, которые со временем превратились в эвтрофное болото. Соответственно, направленные пространственно-временные изменения концентраций химических элементов в торфах, ОМО, минеральном грунте и болотных водах могут рассматриваться, во-первых, в статистическом смысле в среднем для выделенного таксономического элемента болотной экосистемы и/или этапа ее эволюции. Во-вторых, в пограничных слоях болотной экосистемы из-за дифференциации источников вещества и условий его аккумуляции и миграции вероятно формирование геохимических и биогеохимических барьеров, которые затем испытывают воздействие факторов, возникших уже в новой среде.

В результате этого наблюдаемые изменения концентраций многих химических элементов выражены недостаточно ярко, но тем не менее не являются хаотическими, а вполне закономерны. Например, содержания фосфора в верхнем слое, сформировавшемся преимущественно в условиях атмосферного водно-минерального питания и сезонного потребления болотной растительностью, заметно меньше содержаний в нижележащем слое, сложенном низинными и переходными торфами, в которых в составе минеральных включений кальцит встречается несколько чаще, чем в слое 0,00-1,25 м. В нижнем же слое колебания концентраций Р могут быть связаны с сорбцией анионных форм этого элемента на агрегатах, в составе которых присутствуют карбонаты и гуматы кальция, гидроксиды железа и алюминия [50, 51, 56, 57]. Еще один пример - распределение по разрезу серы, повышенные концентрации которой в общих чертах приурочены к границам деятельного и инертного горизонта (смена окислительной обстановки на восстановительную), верховых и переходных, переходных и низинных торфов (табл. 2).

Нельзя обойти вниманием и распределение по разрезу торфяной залежи свинца, повышенные концентрации которого часто связывают с антропогенным влиянием. В частности, в торфяниках Европы пики концентраций этого элемента иногда сопоставляются с развитием промышленности современных и древних государств [58]. В пределах рассматриваемого участка Васюганского болота максимальные концентрации $\mathrm{Pb}(16,9$ мг/кг) действительно обнаружены в верхнем слое торфяной залежи ряма $(0,00-0,25$ м), но почти такие же концентрации 11-14 мг/кг отмечены на глубинах 2,5-4,5 м (то есть 2,5-4,5 тыс. лет назад) в торфах, OMO, минеральном грунте и почве в заболоченном лесу. Сложно предположить, что добыча и переработка свинцовых руд в Римской империи или других, в том числе еще более древних государствах, повлияли на химический состав торфов в районе, удаленном на тысячи километров. Более правдоподобным, видимо, является предположение о поступлении $\mathrm{Pb}, \mathrm{Zn}, \mathrm{Ti}, \mathrm{Hg}$, U и ряда других элементов с атмосферным аэрозолем и/или с твердым стоком с прилегающих территорий и о последующем накоплении вследствие преобладания скорости аккумуляции над скоростью выноса [5]. В частности, в инертном горизонте торфяной залежи вероятно образование сульфидных минералов $\mathrm{Pb}, \mathrm{Zn}, \mathrm{Fe}$ ниже границы распространения микрофлоры, потребляющей восстановленные соединения серы, при условии минимального уровня содержаний веществ (например, ионов $\mathrm{Al}^{3+}$ и $\mathrm{NO}_{2}^{-}$), которые препятствуют ее существованию [14]).

Среди факторов, определяющих формирование геохимических барьеров, следует отметить, прежде всего, резкое сокращение доступа кислорода в верхнем деятельном слое $0,25-0,50$ м, биоаккумуляцию, ее сезонные и многолетние изменения, условия пространственно-временной дифференциации водно-минерального питания, включая условия выноса или трансформации токсичных для микро- и макрофлоры продуктов, различную доступность твердого вещества, различия фильтрационных свойств органического и минерального грунта и их многолетнюю динамику с учетом типов и видов торфа. В последних двух случаях важно отметить, что изменения минерального состава грунтов в болотной среде могут сопровождаться кольматацией придонного слоя торфяной залежи в процессе возникновения и эволюции болота, в том числе, за счет осаждения малорастворимых соединений. При условии отсутствия значимого бокового водного, твердого и химического притока с прилегающих суходолов это может быть важным дополнительным фактором изменения типа болотной экосистемы (с евтрофного на мезотрофный и с мезотрофного на олиготрофный) и концентрирования химических элементов на границе слоев с разными фильтрационными, физико-химическими и геохимическими свойствами.

\section{Заключение}

Как показал анализ химического состава кислотных вытяжек из торфов, органо-минеральных отложений и минерального грунта с использованием метода масс-спектрометриии с индуктивно связанной плазмой, все изученные химические элементы можно условно разделить на группы: 1) с относительно устойчивым увеличением от поверхности к минеральным грунтам и/или ярко выраженным максимумом в минеральных грунтах - Li, $\mathrm{Al}, \mathrm{Be}, \mathrm{Mg}, \mathrm{Ca}, \mathrm{Sr}, \mathrm{Fe}, \mathrm{V}, \mathrm{Cr}, \mathrm{Mn}, \mathrm{Ni}, \mathrm{J}, \mathrm{Ba}, \mathrm{Cs}, \mathrm{Ce}$, $\mathrm{La}, \mathrm{Sm}, \mathrm{Eu}, \mathrm{Dy}, \mathrm{Tb}, \mathrm{Yb}, \mathrm{Lu}, \mathrm{Ho}, \mathrm{Gd}, \mathrm{Th}$, в том числе с небольшим (по сравнению с максимумом в минеральном грунте) повышением концентраций в верхней части разреза $\mathrm{Cu}, \mathrm{Ga}, \mathrm{Ge}, \mathrm{Rb}, \mathrm{Zr}, \mathrm{Hf}$; 2) с хорошо выраженными максимумами в верхней и нижней частях разреза - $\mathrm{Na}, \mathrm{K}, \mathrm{Ti}, \mathrm{Pb}, \mathrm{Hg}, \mathrm{Rb}, \mathrm{Cd}$, $\mathrm{Sb}, \mathrm{Sn}, \mathrm{W}, \mathrm{Bi}, \mathrm{Si}$, в том числе, с резко выраженной дифференциацией по разрезу $\mathrm{Pb}$ и $\mathrm{Bi}$; 3) с иными типами распределения - S, P, U, Au, Ag, Pt, Zn, As, Re, Os, B, Br, Ta.

Основными факторами пространственных изменений химического состава торфов, ОМО и ми- 
нерального грунта в целом являются природные биогеохимические условия, интенсивность водообмена, соотношение атмосферного и грунтового водного и минерального питания, определяющие общую доступность воды и питательных веществ для болотной растительности, отвод токсичных для этой растительности веществ. Перечисленные факторы изменяются во времени как внутри года, так и в многолетнем разрезе, причем изменения часто носят случайный и дискретный характер и соответствуют изменению типа болотных экосистем и торфов. Влияние антропогенных факторов исключить нельзя, но непосредственно на рассматриваемом участке Васюганского болота их роль минимальна. Например, наблюдаемые повышенные концентраций $\mathrm{Na}, \mathrm{K}, \mathrm{Bi}, \mathrm{Ti}, \mathrm{Pb}$ и других элементов в деятельном горизонте торфяной залежи с большей вероятностью объясняются выщелачиванием и растворением минералов, входящих в состав регионального атмосферного аэрозоля. Безусловно, атмосферный аэрозоль может иметь и природно-антропогенное происхождение [59], но сопоставление с данными о химическом составе горных пород и почв на юге Томской области и прилегающих территориях [47, 60-62] все же свидетельствует о преобладании природных факторов (например, судя по содержанию Ti).

В процессе замедленного, но все же имеющего место быть водоомена происходит вынос свинца и других химических элементов по линиям стекания в деятельном горизонте (с определенной аккумуляцией в грядах грядово-мочажинного ком-

\section{СПИСОК ЛИТЕРАТУРЫ}

1. Болотные воды Томской области / Н.М. Рассказов, П.А. Удодов, А.Д. Назаров, Т.Я. Емельянова // Известия Томского политехнического института. - 1975. - Т. 297. -С. 102-117.

2. Геохимия растений и торфов Большого Васюганского болота / В.К. Бернатонис, В.С. Архипов, М.А. Здвижков, Ю.И. Прейс, Н.0. Тихомирова // Большое Васюганское болото. Современное состояние и процессы развития / под ред. М.В. Кабанова. Томск: Изд-во ИОА СО РАН, 2002. - С. 204-215.

3. Среднее содержание некоторых элементов-примесей в торфах юго-восточной части Западно-Сибирской плиты / С.И. Арбузов, В.С. Архипов, В.К. Бернатонис, В.А. Бобров, С.Г. Маслов, А.М. Межибор, Ю.И. Прейс, Л.П. Рихванов, А.Ф. Судыко, А.И. Сысо // Известия Томского политехнического университета. - 2009. - Т. 315. - № 1. - С. 44-48.

4. Архипов В.С., Бернатонис В.К. Распределение кальция и железа в вертикальном профиле торфяных залежей таёжной 30ны Западной Сибири // Известия Томского политехнического университета. - 2013. - Т. 323. - № 1. - С. 173-178.

5. Геологическая эволюция и самоорганизация системы вода-порода: в 5 т. Т. 2. Система вода-порода в условиях зоны гипергенеза / С.Л. Шварцев, Б.Н. Рыженко, В.А. Алексеев, Е.М. Дутова, И.А. Кондратьева, Ю.Г. Копылова, О.Е. Лепокурова / отв. ред. Б.Н. Рыженко. - Новосибирск: СО РАН, 2007. - 389 с

6. Савичев 0.Г., Мазуров А.К. Временные изменения химического состава вод в восточной части Васюганского болота (Западная Сибирь) // Известия Томского политехнического университета. Инжиниринг георесурсов. - 2018. - Т. 329. - № 2. C. $38-48$. плекса и ряме), а также поступление в инертный горизонт, где вероятно образование сульфидных минералов, включая галенит и пирит (табл. 2). В годы с различной водностью скорость выноса меняется прямо пропорционально атмосферному увлажнению, что объясняет обнаружение в ряме наиболее высокой концентрации $\mathrm{Pb}(16,9 \mathrm{мг} / к г)$ в марте 2017 г. после засушливой осени 2016 г. (сумма осадков за сентябрь-ноябрь - 73 мм). Oсенью 2017 г. выпало заметно больше атмосферных осадков (сумма осадков за сентябрь-ноябрь 93 мм). Соответственно, увеличилась скорость гидрохимического выноса, а максимальная концентрация свинца в марте 2018 г. составила уже $6,6 \mathrm{мг} / \mathrm{кг.}$

Необходимо отметить, что в речных системах и подземных водах зоны гипергенеза обычно наблюдается обратная зависимость между интенсивностью водообмена и уровнем содержания в воде веществ [44, 63]. На самом деле, как было показано в [64], противоречий нет, поскольку для всего диапазона изменений эта зависимость при определенных условиях имеет вид, близкий к гаммафункции. Нелинейный характер имеет и большинство других зависимостей, описывающих взаимосвязи между геологическими, геохимическими, биогеохимическими и гидрологическими процессами, что и сказывается на характере распределения химических элементов по глубине и территории болотных экосистем.

Работа выполнена при финансовой поддержке Правительства РФ (контракт № 14.Z50.31.0012).

7. Modes of occurrence of rare earth elements in peat from Western Siberia / S.I. Arbuzov, S.G. Maslov, R.B. Finkelman, A.M. Mezhibor, S.S. Ilenok, M.G. Blokhin, E.V. Peregudina // Journal of Geochemical Exploration. - 2017. - V. 10. - P. 1-22. URL: https://doi.org/10.1016/j.gexplo.2017.10.012 (дата обращения 12.10.2017).

8. Болотные системы Западной Сибири и их природоохранное значение / О.Л. Лисс, Л.И. Абрамова, Н.А. Аветов, Н.А. Березина, Л.И. Инишева, Т.В. Курнишкова, З.А. Слука, Т.Ю. Толпышева, Н.К. Шведчикова / под ред. В.Б. Куваева. - Тула: Гриф и К ${ }^{\circ}, 2001 .-584$ с.

9. Пологова Н.Н., Лапшина Е.Д. Накопление углерода в торфяных залежах Большого Васюганского болота // Большое Васюганское болото. Современное состояние и процессы развития / под ред. М.В. Кабанова. - Томск: Изд-во ИОА СО РАН, 2002. - C. $174-179$.

10. Eurasian Mires of the Southern Taiga Belt: Modern Features and Response to Holocene Palaeoclimate / T. Minayeva, W. Bleuten, A. Sirin, E.D. Lapshina // Wetlands and Natural Resource Management. Ecological Studies. V. 190 / Eds. J.T.A. Verhoeven, B. Beltman, R. Bobbink, D.F. Whigham. - Berlin; Heidelberg: Springer-Verlag, 2006. - P. 315-341.

11. Савичев 0.Г. Геохимические показатели болотных вод в таежной зоне Западной Сибири // Известия РАН. Серия географическая. - 2015. - № 4. - С. 47-57.

12. Savichev 0.G. Distribution of Inorganic Pollutants over the Depth of Upper Peat Deposit / Contemporary Problems of Ecology. - 2015. - V. 8. - № 1. - P. 118-124.

13. Прогноз изменения макрокомпонентного состава болотных вод при добыче железных руд в Томской области / О.Г. Сави- 
чев, А.К. Мазуров, Н.В. Гусева, В.А. Домаренко, А.А. Хващевская // География и природные ресурсы. - 2016. - № 1. C. $94-102$.

14. Гидрогеохимические условия формирования олиготрофных болотных экосистем / О.Г. Савичев, А.К. Мазуров, И.П. Семилетов, В.А. Базанов, Н.В. Гусева, А.А. Хващевская, Н.Г. Наливайко // Известия РАН. Серия географическая. - 2016. № 5. - C. 60-69. URL: http://dx.doi.org/10.15356/ 0373-2444-2016-5-60-69 (дата обращения 03.11.2017).

15. Домаренко В.А., Савичев 0.Г., Перегудина Е.В. Особенности распределения химических элементов в болотных экосистемах Восточного Васюганья // Разведка охрана недр. - 2017. № 8. - C. $50-55$.

16. The evolution of authigenic $\mathrm{Zn}-\mathrm{Pb}-\mathrm{Fe}$-bearing phases in the Grieves Siding peat, western Tasmania / R. Awid-Pascual, V.S. Kamenetsky, K. Goemann, N. Allen, T.L. Noble, B.G. Lottermoser, T. Rodemann // Contributions to Mineralogy and Petrology. 2015. - № 170. - P. 17. DOI: 10.1007/s00410-015-1167-y.

17. Mineral components in a peat deposit: looking for signs of early mining and smelting activities in Silesia-Cracow region (Southern Poland) / J. Cabala, B. Smieja-Król, M. Jablonska, L. Chrost // Environmental Earth Sciences. - 2013. - № 69. P. 2559-2568. DOI: $10.1007 / \mathrm{s} 12665-012-2080-6$.

18. Formation of sphalerite (ZnS) deposits in natural biofilms of sulfate-reducing bacteria / M. Labrenz, G.K. Druschel, T. ThomsenEbert, B. Gilbert, S.A. Welch, K.M. Kemner, G.A. Logan, R.E. Summons, G. Stasio, P.L. Bond, B. Lai, S.D. Kelly, J.F. Banfield // Science. - 2000. - № 290. - P. 1744-1747.

19. Shotyk W. Review of the inorganic geochemistry of peats and peatland waters // Earth-Science Reviews. - 1988. - № 25. P. 95-176. DOI: $10.1016 / 0012-8252(88) 90067-0$.

20. Kamenov G.D., Brenner M., Tucker J.L. Anthropogenic versus natural control on trace element and $\mathrm{Sr}-\mathrm{Nd}-\mathrm{Pb}$ isotope stratigraphy in peat sediments of southeast Florida (USA), $1500 \mathrm{AD}$ to present // Geochimica et Cosmochimica Acta. - 2009. - № 73. P. 3549-3567. DOI: 10.1016/j.gca.2009.03.017.

21. Potentials and problems of building detailed dust records using peat archives: An example from Store Mosse (the "Great Bog»), Sweden / M.E. Kylander, A. Martínez-Cortizas, R. Bindler, S.L. Greenwood, C.-M. Mörth, S. Rauch // Geochimica et Cosmochimica Acta. - 2016. - № 190. - P. 156-174. DOI: 10.1016/j.gca.2016.06.028.

22. Origins of mineral matter in peat marsh and peat bog deposits, Spain / A.M. López-Buendía, M.K.G. Whateley, J. Bastida, M.M. Urquiola // International Journal of Coal Geology. 2007. - V. 71. - P. 246-262. D0I: 10.1016/j.coal.2006.09.001.

23. Heavy metal release by peat erosion in the Peak District, southern Pennines, UK / J.J. Rothwell, S.G. Robinson, M.G. Evans, J. Yang, T.E.H. Allott // Hydrological Processes. - 2005. № 19. - P. 2973-2989. DOI: 10.1002/hyp.5811.

24. Smieja-Król B., Fiałkiewicz-Kozieł B. Quantitative determination of minerals and anthropogenic particles in some Polish peat occurrences using a novel SEM point-counting method // Environmental Monitoring and Assessment. - 2014. - № 186. P. 2573-2587. DOI: $10.1007 / \mathrm{s} 10661-013-3561-0$.

25. Steinmann P., Shotyk W. Geochemistry, mineralogy, and geochemical mass balance on major elements in two peat bog profiles (Jura Mountains, Switzerland) // Chemical Geology. - 1997. № 138. - P. 25-53. DOI: 10.1016/S0009-2541(96)00171-4.

26. Syrovetnik K., Puura E., Neretnieks I. Accumulation of heavy metals in Oostriku peat bog, Estonia: -Site description, conceptual modelling and geochemical modelling of the source of the metals // Environmental Geology. - 2004. - № 45. - P. 731-740. DOI: $10.1007 / \mathrm{s} 00254-003-0931-\mathrm{x}$.

27. Comparative evaluation of the mineralogical composition of Sphagnum peat and their corresponding humic acids, and implications for understanding past dust depositions / C. Zaccone,
S. Pabst, G.S. Senesi, W. Shotyk, T.M. Miano // Quaternary International. - 2013. - № 306. - P. 80-87. DOI: 10.1016/j.quaint.2013.04.017.

28. Оценка потоков минерального вещества по свойствам торфяных отложений Бакчарского болота (южная тайга Западной Сибири) / Ю.И. Прейс, В.А. Бобров, В.В. Будашкина, B.М. Гавшин // Известия Томского политехнического университета. - 2010. - Т. 316. - № 1. - С. 43-47.

29. Veretennikova E.E. Lead in the natural peat cores of ridge-hollow complex in the taiga zone of West Siberia // Ecological Engineering. - 2015. - V. 80. - P. 100-107.

30. Торфяные ресурсы Томской области. Справочник по состоянию изученности на 01.01.1998 г. - Новосибирск: СНИИГГИМС, 1998. -405 с.

31. Савичева 0.Г., Инишева Л.И. Биологическая активность торфяных болот // Сибирский экологический журнал. - 2000. № 5. - C. 607-614.

32. Научно-исследовательский полигон «Васюганье». Программа научной экскурсии / Л.И. Инишева, Т.В. Дементьева, Е.А. Головацкая, Е.В. Порохина. - Томск: ЦНТИ, 2003. - 88 с.

33. ГОСТ 21123-85. Торф. Термины и определения. Дата введения 01.07.1986 г. - М.: Изд-во стандартов, 1985. - 85 с.

34. Лиштван И.И., Базин Е.Т., Косов В.И. Физические процессы в торфяных залежах. -Минск: Наука и техника, 1989. - 287 с.

35. Маслов Б.С. Гидрология торфяных болот. - М.: Россельхозакадемия, 2009. - 266 с

36. Иванов К.Е. Водообмен в болотных ландшафтах. - Л.: Гидрометеоиздат, 1975. - $280 \mathrm{c.}$

37. Емельянова Т.Я., Крамаренко В.В. Характеристики фильтрационных свойств торфов Томской области // Обской вестник. 2001. - № 1. - C. 36-39.

38. Крамаренко В.В. Характеристика торфяных грунтов Васюганского болота (междуречья Бакчар - Икса - Шегарка) // Иввестия Томского политехнического университета. - 2003. T. 306. - № 6. - C. 28-31.

39. Природные ресурсы центральной части Западно-Сибирской равнины / под ред. Г.В. Добровольского, Е.М. Сергеева, А.С. Герасимовой. - М.: Изд-во МГУ, 1977. - 211 с.

40. Мелиорация и водное хозяйство. Т. 3. Осушение / под ред. Б.С. Маслова. - М.: Агропромиздат, 1985. - 447 с.

41. Гусев Е.М., Насонова 0.Н. Моделирование тепло- и влагообмена поверхности суши с атмосферой. - М.: Наука, 2010. - 327 с.

42. Nash J.E., Sutcliffe J.V. River flow forecasting through conceptual models. P. I. A discussion of principles // Journal of Hydrology. - 1970. - № 10 (3). - P. 282-290.

43. Пособие по определению расчётных гидрологических характеристик / под ред. Т.С. Шмидта. - Л.: Гидрометеоиздат, 1984. $448 \mathrm{c.}$

44. Shvartsev S.L. Geochemistry of fresh Groundwater in the Main Landscape Zones of the Earth // Geochemistry International. 2008. - V. 46. - № 13. - P. 1285-1398.

45. Drever J.I. The geochemistry of natural waters. - Englewood Cliffs: Prentice-Hall, Inc., 1982. - 440 p.

46. Тимофеев П.П., Боголюбова Л.И. Геохимия органического вещества голоценовых отложений в областях приморского торфонакопления. - М.: Наука, 1999. - 220 c.

47. Сысо А.И. Закономерности распределения химических элементов в почвообразующих породах и почвах Западной Сибири: автореф. дис. ... д-ра биол. наук. - Новосибирск, 2004. $32 \mathrm{c}$.

48. Савичев 0.Г., Бернатонис П.В., Бернатонис В.К. Гидрологическое обоснование хозяйственного освоения торфяных болот (на примере водосбора реки Ключ, Западная Сибирь) // Известия Томского политехнического университета. - 2012. - Т. 320. № 1. - C. $155-162$.

49. Ephraim J.H., Allard B. Metal Ion Binding by Humic Substances // Modelling in Aquatic Chemistry / Eds. I. Grenthe, I. Puigdomen- 
ech. - Paris, France: OECD, Nuclear Energy Agency, 1997. P. 207-244.

50. Solubility, Mobility, and Bioaccumulation of Trace Elements: Abiotic Processes in the Rhizosphere / B. Robinson, N. Bolan, S. Mahimairaja, B. Clothier // Trace elements in the environment: biogeochemistry, biotechnology, and bioremediation / Eds. M.N.V. Prasad, Ravi Naidu, Kenneth S. Sajwan. - New York, USA: Taylor \& Francis Group, 2006. - P. 97-110.

51. Мотузова Н.В. Соединения микроэлементов в почвах. Системная организация, экологическое значение, мониторинг. - М.: ЛИБРОКОМ, 2013. - 168 с.

52. Geochemistry of carbonatic/sulphatic soils in the southern Angara region, Russia / Yu.N. Vodyanitskii, N.D. Kiseleva, 0.G. Lopatovskaya, A.T. Savichev // Annals of agrarian science. 2016. - № 14. - P. 140-151. URL: http://dx.doi.org/10.1016/ j.aasci.2016.05.016 (дата обращения 20.08.2018).

53. Наймушина 0.С. Геохимическая эволюция природных вод нижней части бассейна реки Томи: автореф. дис. ... канд. геол.минерал. наук. - Томск, 2014. - 22 с.

54. Крайнов С.Р., Швец В.М. Геохимия подземных вод хозяйственно-питьевого назначения. - М.: Недра, 1987. - 237 с.

55. Особенности метаногенеза на олиготрофных болотах Западной Сибири и оценка факторов среды в связи с корректной экстраполяцией потоков CH4 на большие территории / Т.Т. Ефремова, Н.М. Бажин, И.М. Гаджиев, С.П. Ефремов, Г.А. Махов // Сибирский экологический журнал. - 1998. - № 6. C. $563-570$.

56. Крайнов С.Р., Рыженко Б.Н., Швец В.М. Геохимия подземных вод. Теоретические, прикладные и экологические аспекты / отв. ред Н.П. Лавёров. - М.: Наука, 2004. - 677 с.

57. Савенко А.В. 0 взаимосвязанности внутриводоемных циклов фосфора и железа // Водные ресурсы. - 1998. - Т. 25. - № 3. C. $330-334$.

\section{Информация об авторах}

Савичев О.Г., доктор географических наук, профессор Инженерной школы природных ресурсов Национального исследовательского Томского политехнического университета.

Мазуров A.K., доктор геолого-минералогических наук, профессор Инженерной школы природных ресурсов Национального исследовательского Томского политехнического университета.

Рудмин M.A., кандидат геолого-минералогических наук, доцент Инженерной школы природных ресурсов Национального исследовательского Томского политехнического университета.

Хващевская $\boldsymbol{A} . \boldsymbol{A}$., кандидат геолого-минералогических наук, доцент, заведующая проблемной научно-исследовательской лабораторией гидрогеохимии Инженерной школы природных ресурсов Национального исследовательского Томского политехнического университета.

Даулетова А.Б., студент Инженерной школы природных ресурсов Национального исследовательского Томского политехнического университета.
58. Shotyk W. Peat bog archives of atmospheric metal deposition: geochemical evaluation of peat profiles, natural variations in metal Reviews. - 1996. - V. 4. - P. 149-183.

59. Шатилов А.Ю. Вещественный состав и геохимическая характеристика пылевых атмосферных выпадений на территории Тмск, 2001. - 22 c.

циальный источник развития Западно-Сибирского региона / Л.П. Рихванов, С.С. Кропанин, С.А. Бабенко, А.И. Соловьев, Моветов, Т.Ю. Усова, М.А. Полякова. - Кемерово: Сарс, 2001. $-214 \mathrm{c}$

Экогеохимия почв равнинных 1999. - № 3-4. - C. 82-90.

62. Шайхиев И.Р., Рихванов Л.П. Эколого-геохимические исследования природных сред района Бакчарского железорудного C. $62-78$.

63. Алёкин 0.А. Основы гидрохимии. - Л.: Гидрометеорологическое изд-во, 1970. - $444 \mathrm{c.}$

Improved method for hydrochemical exploration of mineral resVietnam .L. Luyen, O.G. Savichev, V.A. Domarenko, Q.D. Tin // P. 167-180. DOI: $10.15625 / 0866-7187 / 39 / 2 / 9703$.

Поступила 30.08.2018 г. Обского бассейна: автореф. дис. ... канд. геол.-минерал. наук. технического университета - 2015 - T. 326 - № 5 . 
UDC 550.46

\title{
CHANGES IN CHEMICAL COMPOSITION OF ACID EXTRACTS ON DEPTH OF PEAT DEPOSIT OF THE VASYUGAN MIRE ECOLOGICAL SYSTEMS (WESTERN SIBERIA)
}

\author{
Oleg G. Savichev', \\ OSavichev@mail.ru
}

Aleksey K. Mazurov'
AKM@tpu.ru

Maxim A. Rudmin',

RudminMA@tpu.ru

Albina A. Hvashchevskaya',
Garibova@yandex.ru

Aigerim B. Dauletova',

Ikerimdb@gmail.com

1 National Research Tomsk Polytechnic University,

30, Lenin avenue, Tomsk, 634050, Russia.

Relevance. The analysis of changes in chemical and mineral composition of peat and soils is the important stage of searches of minerals, development of corresponding methodology, and methodology of ecological monitoring as well.

The aim of the research is to reveal the changes in chemical composition of peat and soil acid extracts in east part of the Vasyugan mire. Methods: landscape-geochemical and statistical methods, methods of definition of chemical and mineral composition of peat and soils, imitating mathematical modelling.

Results and conclusions. According to approbation of peats and mineral soils in March 2017 and 2018 in east part of the Vasyugan mire (Western Siberia, the Ob river basin, the Russian Federation) the authors have analyzed: chemical composition of acid extracts from peats and soils using ICP MS; composition of mineral inclusions in peat and soils using the method of scanning electronic microscopy and XRD-analysis. Concentration of 73 chemical elements was determined and three groups of elements were allocated: 1) with rather steady increase from a surface to bottom soils and/or a strongly pronounced maximum in bottom soils; 2) with well expressed maxima in the top and bottom parts of peat deposits; 3) with other types of distribution. The major factors of spatial changes in chemical composition of peat and soils are mainly natural biogeochemical conditions, water exchange intensity, ratio of the atmospheric and ground water and mineral feed which determine the common availability of water and nutrients for bog vegetation, removal of toxic substances for this vegetation.

Key words:

Vasyugan mire, peat, soils, chemical composition, mineral composition, change on peat deposition depth.

The research was financially supported by the Russian Government (grant 14.Z50.31.0012).

\section{REFERENCES}

1. Rasskazov N.M., Udodov P.A., Nazarov A.D., Emelyanova T.Ya. Bolotnye vody Tomskoy oblasti [Swamp waters]. Bulletin of the Tomsk Polytechnic Institute, 1975, vol. 297, pp. 102-117.

2. Bernatonis V.K., Arkhipov V.S., Zdvizhkov M.A., Preys Yu.I., Tikhomirova N.0. Geokhimiya rasteniy i torfov Bolshogo vasyuganskogo bolota [Geochemistry of plants and peats of the Great Vasyugan bog]. Bolshoe Vasuganskoe boloto. Sovremennoe sostoyanie i protsessy razvitiya [Big Vasyugan bog. Current status and development]. Tomsk, Institute of Atmospheric Optics SB RAS Publ., 2002. pp. 204-215.

3. Arbuzov S.I., Arkhipov V.S., Bernatonis V.K., Bobrov V.A., Maslov S.G., Mezhibor A.M., Preis Yu.I., Rikhvanov L.P., Sudyko A.F., Syso A.I. Average content of several elements-admixtures in peats of south-east part of Western-Siberian plate. Bulletin of the Tomsk Polytechnic University, 2009, vol. 315, no. 1, pp. 44-48. In Rus.

4. Arkhipov V.S., Bernatonis V.K. Distribution of calcium and iron in the vertical profile of peat deposits in the taiga zone of Western Siberia. Bulletin of the Tomsk Polytechnic University, 2013, vol. 323 , no. 1, pp. 173-178. In Rus.
5. Shvartsev S.L., Ryzhenko B.N., Alekseev V.A., Dutova E.M., Kondratieva I.A., Kopylova Yu.G., Lepokurova 0.E. Geologicheskaya evolyutsiya i samoorganizatsiya sistemy voda-poroda. T. 1. Sistema voda-poroda $v$ usloviyakh zony gipergeneza [Geological evolution and self-organizing of water-rock system. V. 1. Water-rock system in conditions of a zone of active water exchange]. Ed. by B.N. Ryzhenko. Novosibirsk, Siberian Branch of the Russian Academy of Science Publ. house, 2007. 389 p.

6. Savichev 0.G., Mazurov A.K. Changes of chemical composition of waters in East Part of the Vasyugan Mire (Western Siberia). Bulletin of the Tomsk Polytechnic University. Geo Assets Engineering, 2018, vol. 329, no. 2, pp. 38-48. In Rus.

7. Arbuzov S.I., Maslov S.G., Finkelman R.B., Mezhibor A.M., Ilenok S.S., Blokhin M.G., Peregudina E.V. Modes of occurrence of rare earth elements in peat from Western Siberia. Journal of Geochemical Exploration, 2017, no. 10, pp. 1-22. Available at: https://doi.org/10.1016/j.gexplo.2017.10.012 (accessed 12 0ctober 2017).

8. Liss O.L., Abramova L.I., Avetov N.A. Bolotnye sistemy Zapadnoy Sibiri i ikh prirodookhrannoe znachenie [Bog of Western Siberia and their conservation value]. Tula, Grif i K ${ }^{\circ}$ Publ., 2001. $584 \mathrm{p}$. 
9. Pologova N.N., Lapshina E.D. Nakoplenie ugleroda v torfyanykh zalezhakh Bolshogo Vasuganskogo bolota [Carbon accumulation in peat bog deposits of the Great Vasyugan]. Bolshoe Vasuganskoe boloto. Souremennoe sostoyanie i protsessy razvitiya [Big Vasyugan bog. Current status and development]. Tomsk, Institute of Atmospheric Optics SB RAS Publ., 2002. pp. 174-179.

10. Minayeva T., Bleuten W., Sirin A., Lapshina E.D. Eurasian Mires of the Southern Taiga Belt: Modern Features and Response to Holocene Palaeoclimate. Wetlands and Natural Resource Management. Ecological Studies. Vol. 190. Eds. J.T.A. Verhoeven, B. Beltman, R. Bobbink, D.F. Whigham. Berlin, Heidelberg, Springer-Verlag, 2006. pp. 315-341.

11. Savichev 0.G. Geochemical indicators of bog waters in the taiga zone of Western Siberia. Izvestiya RAN. Seriya geograficheskaya, 2015, no. 4, pp. 47-57. In Rus.

12. Savichev 0.G. Distribution of Inorganic Pollutants over the Depth of Upper Peat Deposit. Contemporary Problems of Ecology, 2015, vol. 8, no. 1, pp. 118-124.

13. Savichev 0.G., Mazurov A.K., Guseva N.V., Domarenko V.A., Khvashchevskaya A.A. The forecast of change of macrocomponental composition of wetland waters at extraction of minerals in the Tomsk region. Geography and natural resources, 2016, no. 1, pp. 94-102. In Rus.

14. Savichev 0.G., Mazurov A.K., Semiletov I.P., Bazanov V.A., Guseva N.V., Khvashchevskaya A.A., Nalivayko N.G. Hydrogeochemical conditions of formation of oligotrophic bog ecosystems. Iz vestiya Rossiiskoi Akademii Nauk. Seriya Geograficheskaya, 2016, no. 5, pp. 60-69. In Rus. Available at: http://dx.doi.org/10.15356/0373-2444-2016-5-60-69 (accessed 03 November 2017).

15. Domarenko V.A., Savichev 0.G., Peregudina E.V. Peculiarities of the distribution of chemical elements in the marsh ecosystems of Eastern Vasyuganie. Razvedka i okhrana nedr, 2017, no. 8, pp. 50-55. In Rus.

16. Awid-Pascual R., Kamenetsky V.S., Goemann K., Allen N., Noble T.L., Lottermoser B.G., Rodemann T. The evolution of authigenic $\mathrm{Zn}-\mathrm{Pb}-\mathrm{Fe}$-bearing phases in the Grieves Siding peat, western Tasmania. Contributions to Mineralogy and Petrology, 2015, no. 170, p. 17. DOI: $10.1007 / \mathrm{s} 00410-015-1167-y$.

17. Cabala J., Smieja-Król B., Jablonska M., Chrost L. Mineral components in a peat deposit: looking for signs of early mining and smelting activities in Silesia-Cracow region (Southern Poland). Environmental Earth Sciences, 2013, no. 69, pp. 2559-2568. DOI: $10.1007 / \mathrm{s} 12665-012-2080-6$.

18. Labrenz M., Druschel G.K., Thomsen-Ebert T., Gilbert B., Welch S.A., Kemner K.M., Logan G.A., Summons R.E., Stasio G., Bond P.L., Lai B., Kelly S.D., Banfield J.F. Formation of sphalerite $(\mathrm{ZnS})$ deposits in natural biofilms of sulfate-reducing bacteria. Science, 2000, no. 290, pp. 1744-1747.

19. Shotyk W. Review of the inorganic geochemistry of peats and peatland waters. Earth-Science Reviews, 1988, no. 25, pp. 95-176. DOI: $10.1016 / 0012-8252(88) 90067-0$.

20. Kamenov G.D., Brenner M., Tucker J.L. Anthropogenic versus natural control on trace element and $\mathrm{Sr}-\mathrm{Nd}-\mathrm{Pb}$ isotope stratigraphy in peat sediments of southeast Florida (USA), $1500 \mathrm{AD}$ to present. Geochimica et Cosmochimica Acta, 2009, no. 73, pp. 3549-3567. DOI: 10.1016/j.gca.2009.03.017.

21. Kylander M.E., Martínez-Cortizas A., Bindler R., Greenwood S.L., Mörth C.-M., Rauch S. Potentials and problems of building detailed dust records using peat archives: An example from Store Mosse (the «Great Bog»), Sweden. Geochimica et Cosmochimica Acta, 2016, no. 190, pp. 156-174. D0I: 10.1016/j.gca.2016.06.028.

22. López-Buendía A.M., Whateley M.K.G., Bastida J., Urquiola M.M. Origins of mineral matter in peat marsh and peat bog deposits, Spain. International Journal of Coal Geology, 2007, vol. 71, pp. 246-262. DOI: 10.1016/j.coal.2006.09.001.
23. Rothwell J.J., Robinson S.G., Evans M.G., Yang J., Allott T.E.H. Heavy metal release by peat erosion in the Peak District, southern Pennines, UK. Hydrological Processes, 2005, no. 19, pp. 2973-2989. DOI: $10.1002 /$ hyp.5811.

24. Smieja-Król B., Fiałkiewicz-Kozieł B. Quantitative determination of minerals and anthropogenic particles in some Polish peat occurrences using a novel SEM point-counting method. Environmental Monitoring and Assessment, 2014, no. 186, pp. 2573-2587. DOI: 10.1007/s10661-013-3561-0.

25. Steinmann P., Shotyk W. Geochemistry, mineralogy, and geochemical mass balance on major elements in two peat bog profiles (Jura Mountains, Switzerland). Chemical Geology, 1997, no. 138, pp. 25-53. DOI: 10.1016/S0009-2541(96)00171-4.

26. Syrovetnik K., Puura E., Neretnieks I. Accumulation of heavy metals in Oostriku peat bog, Estonia: Site description, conceptual modelling and geochemical modelling of the source of the metals. Environmental Geology, 2004, no. 45, pp. 731-740. D0I: 10.1007/s00254-003-0931-x.

27. Zaccone C., Pabst S., Senesi G.S., Shotyk W., Miano T.M. Comparative evaluation of the mineralogical composition of Sphagnum peat and their corresponding humic acids, and implications for understanding past dust depositions. Quaternary International, 2013, no. 306, pp. 80-87. DOI: 10.1016/j.quaint.2013.04.017.

28. Preiss Yu.I., Bobrov V.A., Budashkina V.V., Gavshin V.M. Estimation of streams of mineral substance on properties of peat sediments of the Bakchar mire (a southern taiga zone of the Western Siberia). Bulletin of the Tomsk Polytechnic University, 2010, vol. 316, no. 1, pp. 43-47. In Rus.

29. Veretennikova E.E. Lead in the natural peat cores of ridge-hollow complex in the taiga zone of West Siberia. Ecological Engineering, 2015, vol. 80, pp. 100-107.

30. Torfyanyye resursy Tomskoy oblasti. Spravochnik po sostoyaniyu izuchennosti na 01.01.1998 [Peat resources of the Tomsk region. A handbook on the state of knowledge at 01.01.1998]. Novosibirsk, SNIIGGIMS Publ., 1998. 405 p.

31. Savicheva 0.G., Inisheva L.I. Biologicheskaya aktivnost torfyanykh bolot [Biological activity of peat bogs]. Contemporary Problems of Ecology, 2000, no. 5, pp. 607-614.

32. Inisheva L.I., Dementyeva T.V., Golovatskaya E.A., Porokhina E.V. Nauchno-issledovatelskiy poligon «Vasyuganye». Programma nauchnoy ekskursii [Scientific-research ground «Vasyugane». Program of scientific excursion]. Tomsk, TSNTI Publ., $2003.88 \mathrm{p}$

33. GOST. Torf. Terminy i opredeleniya [State Standard 21123-85. Peat. Terms and definitions]. 01.07.1986. Moscow, Izdatelstvo standartov, $1985.85 \mathrm{p}$.

34. Lishtvan I.I., Bazin E.T., Kosov V.I. Fizicheskiye protsessy v torfyanykh zalezhakh [Physical processes in peat deposits]. Minsk, Nauka i tekhnika Publ., 1989. 287 p.

35. Maslov B.S. Gidrologiya torfyanykh bolot [Hydrology of peat bogs]. Moscow, Rosselkhozakademiya Publ., 2009. 266 p.

36. Ivanov K.E. Vodoobmen $v$ bolotnykh landschaftakh [Water exchange in mire landscapes]. Leningrad, Gidrometeoizdat Publ., $1975.280 \mathrm{p}$.

37. Emelyanova T.Ya., Kramarenko V.V. Kharakteristiki filtratsionnykh svoystv torfov Tomskoy oblasti [Characteristic of filtrational properties of peats of Tomsk area]. Obskoy vestnik, 2001, no. 1 , pp. $36-39$.

38. Kramarenko V.V. Kharakteristika torfyanykh gruntov Vasyuganskogo bolota (mezhdurechya Bakchar-Iksa-Shegarka) [Characteristic of peat soils of Vasyugan mire (basin between the Bakcar, Iksa and Sgegarka rivers)]. Bulletin of the Tomsk Polytechnic University, 2003, vol. 306, no. 6, pp. 28-31. In Rus.

39. Prirodnye resursy tsentralnoy chasti Zapadno-Sibirskoy ravniny [Natural resources of the central part of West Siberian plain]. Ed. by G.V. Dobrovolsky, E.M. Sergeev, A.S. Gerasimova. Moscow, Moscow State University Press, 1977. 211 p. 
40. Melioratsiya i vodnoe khozyaystvo. Vol. 3. Osushenie [Land improvement and water management. Vol. 3. Drainage]. Ed. by B.S. Maslov. Moscow, Agropromizdat Publ., 1985. 447 p.

41. Gusev E.M., Nasonova 0.N. Modelirovanie teplo- $i$ vlagoobmena poverkhnosti sushi s atmosferoy [Modelling of warm and moisture exchange of a land surface with an atmosphere]. Moscow, Nauka Publ., 2010. $327 \mathrm{p}$.

42. Nash J.E., Sutcliffe J.V. River flow forecasting through conceptual models. P. I. A discussion of principles. Journal of Hydrology, 1970, no. 10 (3), pp. 282-290.

43. Posobie po opredeleniyu rasschetnykh gidrologischeskikh kharakteristik [Manual in definition of hydrological characteristics]. Ed. by T.S. Schmidt. Leningrad, Gidrometeoizdat Publ., 1984. 448 p.

44. Shvartsev S.L. Geochemistry of fresh Groundwater in the Main Landscape Zones of the Earth. Geochemistry International, 2008, vol. 46 , no. 13, pp. 1285-1398.

45. Drever J.I. The geochemistry of natural waters. Englewood Cliffs, Prentice-Hall, Inc., 1982. 440 p.

46. Timofeev P.P., Bogolyubova L.I. Geokhimiya organicheskogo veshchestua golotsenovykh otlozheniy $v$ oblastyakh primorskogo torfonakopleniya [Geochemistry of organic substance of the holocene deposits seashore areas of peat accumulation]. Moscow, Nauka Publ., 1999. 220 p.

47. Syso A.I. Zakonomernosti raspredeleniya khimicheskikh elemen tov v pochvoobrazuyushchikh porodakh i pochvakh Zapadnoy Sibi ri. Avtoref. Dokt. nauk [Laws of distribution of chemical elements in rocks and soils of Western Siberia. Dr. Diss. Abstract]. Novosibirsk, 2004. $32 \mathrm{p}$.

48. Savichev 0.G., Bernatonis P.V., Bernatonis V.K. Hydrological substantiation of economic development of marshes (by the example of the Kluch river basin, the Western Siberia). Bulletin of the Tomsk Polytechnic University, 2012, vol. 320, no. 1, pp. 155-162. In Rus.

49. Ephraim J.H., Allard B. Metal Ion Binding by Humic Substances. Modelling in Aquatic Chemistry. Eds. I. Grenthe, I. Puigdomenech. Paris, France, OECD, Nuclear Energy Agency, 1997. pp. 207-244.

50. Robinson B., Bolan N., Mahimairaja S., Clothier B. Solubility, Mobility, and Bioaccumulation of Trace Elements: Abiotic Processes in the Rhizosphere. Trace elements in the environment: biogeochemistry, biotechnology, and bioremediation. Eds. M.N.V. Prasad, Ravi Naidu, Kenneth S. Sajwan. New York, USA, Taylor \& Francis Group, 2006. pp. 97-110.

51. Motuzova N.V. Soedineniya mikroelementov v pochvakh. Sistemnaya organizatsiya, ekologicheskoe znachenie, monitoring [Microelements in soils. System organization, ecological value, monitoring]. Moscow, LIBROCOM Publ., 2013. 168 p.

52. Vodyanitskii Yu.N., Kiseleva N.D., Lopatovskaya 0.G., Savichev A.T. Geochemistry of carbonatic/sulphatic soils in the southern Angara region, Russia. Annals of agrarian science, 2016, no. 14, pp. 140-151. Available at: http://dx.doi.org/ 10.1016/j.aasci. 2016.05.016 (accessed 20 August 2018).

53. Naymushina 0.S. Geokhimicheskaya evolyutsiya prirodnykh vod nizhney chasti basseyna reki Tomi. Avtoreferat Kand. nauk
[Geochemical evolution of natural waters of the bottom part of the Tom river basin. Cand. Diss. Abstract]. Tomsk, 2014. 22 p.

54. Kraynov S.R., Shvets V.M. Geokhimiya podzemnykh vod khozyaystvenno-pitevogo naznacheniya [Geochemistry of ground waters of economic-drinking assignment]. Moscow, Nedra Publ., 1987. $237 \mathrm{p}$.

55. Efremova T.T., Bazhin N.M., Gadzhiyev I.M., Efremov S.P., Makhov G.A. Osobennosti metanogeneza na oligotrofnykh bolotakh Zapadnoy Sibiri i otsenka faktorov sredy v svyazi s korrektnoy ekstrapolyatsiey potokov $\mathrm{CH}_{4}$ na bolshie territorii [Features of formation of methane on oligotrophic bogs of Western Siberia and estimation of environmental factors in relation to the correct extrapolation of $\mathrm{CH}_{4}$ streams on the big territories]. Contemporary Problems of Ecology, 1998, no. 6, pp. 563-570.

56. Kraynov S.R., Ryzhenko B.N., Shvets V.M. Geokhimiya podzemnykh vod: teoreticheskie, prikladnye $i$ ekologicheskie aspekty [Geochemistry of ground waters: theoretical, applied and environmental aspects]. Moscow, Nauka Publ., 2004. 677 p.

57. Savenko A.V. 0 vzaimosvyazannosti vnutrivodoemnykh tsiklov fosfora i zheleza [On interconnectedness of intrabasin cycles of phosphorus and iron]. Water resources, 1998, vol. 25, no. 3, pp. 330-334.

58. Shotyk W. Peat bog archives of atmospheric metal deposition: geochemical evaluation of peat profiles, natural variations in metal concentration, and metal enrichment factors. Environmental Reviews, 1996, vol. 4, pp. 149-183.

59. Shatilov A.Yu. Veshchestvenny sostav $i$ geokhimicheskaya kharakteristika pyleoykh atmosfernykh vypadeniy na territorii $\mathrm{Ob}$ skogo basseyna. Avtoreferat Dis. Kand. nauk [Material structure and geochemical characteristic of atmospheric losses in the $\mathrm{Ob} \mathrm{ri-}$ ver basin. Cand. Diss. Abstract]. Tomsk, 2001. 22 p.

60. Rikhvanov L.P., Kropanin S.S., Babenko S.A., Solovyev A.I., Sovetov V.M., Usova T.Yu., Polyakova M.A. Tsirkon-ilmenitovye rossypnye mestorozhdeniya kak potentsialy istochnik razvitiya Zapadno-Sibirskogo regiona [Zircon-ilmenite placer mines as a potential source of West Siberian region exploration]. Kemerovo, Sars Publ., 2001. 214 p.

61. Kalinin Yu.A., Roslyakov N.A. Ekogeokhimiya pochv ravninnykh landshaftov yuga Zapadnoy Sibiri [Ecogeochemistry of soils of flat landscapes in the south of Western Siberia]. Obskoy vestnik, 1999, no. 3-4, pp. 82-90.

62. Shaykhiyev I.R., Rikhvanov L.P. Ecological and geochemical research of natural environment in Bakchar iron-ore deposit area (Tomsk region). Bulletin of the Tomsk Polytechnic University, 2015, vol. 326, no. 5, pp. 62-78. In Rus.

63. Alekin 0.A. Osnovy gidrokhimii [Bases of hydrochemistry]. Leningrad, Gidrometeoizdat Publ., 1970. 444 p.

64. Luyen V.L., Savichev 0.G., Domarenko V.A., Tin Q.D. Improved method for hydrochemical exploration of mineral resources. Vietnam Journal of Earth Sciences, 2017, vol. 39, no. 2, pp. 167-180. DOI: $10.15625 / 0866-7187 / 39 / 2 / 9703$.

Received: 30 August 2018.

\section{Information about the authors}

Oleg G. Savichev, Dr. Sc., professor, National Research Tomsk Polytechnic University.

Aleksey K. Mazurov, Dr. Sc., professor, National Research Tomsk Polytechnic University.

Maxim A. Rudmin, Cand. Sc., associate professor, National Research Tomsk Polytechnic University.

Albina A. Hvashchevskaya, Cand. Sc., associate professor, National Research Tomsk Polytechnic University.

Aigerim B. Dauletova, student, National Research Tomsk Polytechnic University. 